\title{
Staging Rachel: Rabbinic Midrash, Theatrical Mime, and Christian Martyrdom in Late Antiquity*
}

Fotini Hadjittofi

University of Lisbon; f.hadjittofi@campus.ul.pt

Hagith Sivan

University of Kansas; dinah01@ku.edu

\section{Abstract}

Lamentations Rabbah Proem 24, a late ancient rabbinic midrash, is in many ways a unique text within the entire rabbinic corpus. It presents an extraordinary array of characters (including Abraham, Moses, the Torah, and even the alphabet) who are called upon to placate God, but fail. As their quest proves inconclusive, the biblical Rachel jumps into the fray to tell her story: how out of sisterly compassion she allowed Leah to take her own place in the conjugal bed on "her" wedding night. Disclosing to her sister the secretive "signs" she had shared with Jacob, Rachel crawled under the nuptial bed to respond to Jacob whenever he spoke. This scandalous autobiography transforms an apparent instance of illicit sex, the ideal material for theatrical stage mimes, into an act of martyrdom and sublime compassion. This article argues that the performance culture of the late ancient Mediterranean world provides the key for assessing this text's originality. We begin with an analysis of the text, drawing attention to its theatrical qualities and its relationships with contemporary visual imagery (mosaics) and texts from outside the rabbinic milieu (Christian Apocrypha). We then examine the casting of midrashic Rachel as a response to both the mimic adulteress and the Christian martyr. Finally, we consider rabbinic familiarity with mime, particularly with its

\footnotetext{
* Fotini Hadjittofi gratefully acknowledges the financial support of FCT (Fundação para a Ciência e a Tecnologia), Portugal, through the project PTDC/LLT LES/30930/2017 (national funds).
} 
usefulness as a social mediator and agent of collective catharsis. It is precisely these aspects of mimic performance, we argue, that Rachel's vignette appropriates in this fascinating rabbinic text.

\section{Keywords}

Rachel biblical matriarch; Midrash; Piyyut; mime; martyrdom

\section{Introduction}

Midrash Lamentations Rabbah or Rabbati (hereafter LamR), an expansive exegesis on the slim biblical book of Lamentations, contains in its present format five "chapters" of uneven length corresponding to those of the biblical scroll of Lamentations. ${ }^{1}$ The midrash is "prefaced" by no less than thirty-four introductory sermons or proemia (פתיחות), likewise of unequal length. ${ }^{2}$ Each proem was

\footnotetext{
${ }^{1}$ All references in this study hark back to the 1899 edition of Shlomo Buber, Midrasch Echa Rabbati (Vilna: Rom). There is certainly room for a new edition of Lamentations Rabbah and a comprehensive commentary. Paul D. Mandel's PhD dissertation provides a useful start (Paul D. Mandel, "Midrash Lamentations Rabbati: Prolegomena and a Critical Edition to the Third Parasha" [Hebrew University of Jerusalem, 1997] [Hebrew]). For the dependence of the traditions incorporated in LamR on earlier Palestinian traditions transmitted in the Palestinian Talmud, as well as how the latter were reworked in the midrash, see Paul D. Mandel, "Between Byzantium and Islam: The Transmission of a Jewish Book in the Byzantine and Early Islamic Period," in Transmitting Jewish Traditions: Orality, Textuality and Cultural Diffusion (ed. Yaakov Elman and Israel Gershoni; Studies in Jewish Culture and Society; New Haven: Yale University Press, 2000) 74-106. Mandel also notes two recensions of LamR, one "authentic" that indicates a "free (oral?)" transmission, and a recension of secondary nature that grafted components from other midrashim, such as Genesis Rabbah, onto the original text of LamR (ibid., 87-88). Buber himself "grafted" the proemia, missing in the manuscript that he used for his critical edition, from other, later printed editions. Mandel compares the two recensions, in a couple of instances, in " Kesira' = Lamb: A Study in Midrashim and a Genizah Fragment," Ginze Kedem 1 (2005) 163-70 (Hebrew). In general and briefly, see Hermann Leberecht Strack, Introduction to the Talmud and Midrash (ed. Gunter Stemberger; Minneapolis: Fortress, 1996) 283-87.

${ }^{2}$ Philip S. Alexander, "Rabbinic Paratexts: The Case of Midrash Lamentations Rabbah," in In the Second Degree: Paratextual Literature in Ancient Near Eastern and Ancient Mediterranean Culture and Its Reflections in Medieval Literature (ed. Philip S. Alexander, Armin Lange, and Renate J. Pillinger; Leiden: Brill, 2010) 183-204, locates the proemia in the synagogue because they have a sermon form and are sprinkled lavishly with Galilean Aramaic, unlike the exclusive use of Hebrew in the chapter commentary. In addition, significant parallels between the proemia and synagogal Palestinian piyyutim for the Ninth of Av (below) anchor the former more firmly in the orbit of the synagogue. See also idem, The Targum of Lamentations: Translated, with a Critical Introduction, Apparatus, and Notes (ArBib 17B; Collegeville, MN: Liturgical Press, 2007) 51-54, for a brief overview of the text and its problems, particularly for reasons to place the redaction of the proemia before that of the body of the midrash. On the anomalous large number and length of the proemia of LamR, see Michel G. Distefano, Inner-Midrashic Introductions and Their Influence on Introductions to Medieval Rabbinic Commentaries (SJ 46; Berlin: de Gruyter, 2009) 85-91, and 105-6 on Pr 24 as possibly a late addition. Our analysis suggests that this is not the case but, likely, the opposite is true, namely, that conspicuous elements of the narrative had been in circulation before the 5th cent., the consensus redactional date of LamR. On technical-textual aspects of the proemia, Paul D. Mandel, "On Patah and on Petihah:
} 
transmitted in the name of a different rabbinic authority and was launched by a single biblical verse that triggers a shorter or longer exposition, all but four of which end with an allusion linking the prophet Jeremiah with the first verse of the biblical scroll ("how solitary does the city now sit ..."). Taken together, these rabbinic reflections aspire to replace biblical doom and disaster with hopes of eventual salvation. The consensus date for the redaction of the entire LamR is the early fifth century CE, a date that makes LamR a rough contemporary of Midrash Genesis Rabbah.

Proem 24, the subject of this study, is the longest and most complex of all the proemia. ${ }^{3}$ It is patently a literary patchwork with seams marked by a curt editorial comment: "another interpretation." ${ }^{4}$ This exegetical text, in many ways unique within the entire rabbinic corpus, presents God as irate and mournful in equal measure: after the destruction of the Temple he is in need of both mollification and consolation. ${ }^{5}$ An extraordinary array of characters (including Abraham, Moses, the Torah, and even the alphabet) are called upon to placate God, but none is successful. As their quest proves inconclusive, the biblical Rachel jumps into the scene to tell her story: how out of sisterly compassion she allowed Leah to take her own place in the conjugal bed on "her" wedding night. Disclosing to her sister the secretive "signs" she had shared with Jacob, Rachel crawled under the nuptial bed to respond to Jacob whenever he spoke. If a mortal woman could overcome her envy, so should God. As the midrashic vignette tumbles its listeners from heavenly to domestic spaces - indeed, to the very heart of the hearth, the conjugal bed - God's mercy is stirred and hope is recovered.

To understand the novel and parodic aspects of this midrash, it is vital to examine the text not only in a rabbinic context but also under a comparative light. This article argues that the performance culture of the late ancient Mediterranean world provides the key for assessing this text's originality. Remarkable as the humanization or anthropomorphization of God (already discussed by others) is, several other

A New Study," in Higayon L'Yona: New Aspects in the Study of Midrash, Aggadah, and Piyyut in honor of Professor Yona Fraenkel (ed. Joshua Levinson, Jacob Elbaum, and Galit HasanRokem; Jerusalem: Magnes, 2006) 49-82 (Hebrew), suggests these terms as clues to unearthing hints in biblical verses that would link the proem to biblical events or individuals.

${ }^{3}$ Also named "the most mythological" text in LamR and a forerunner of the androgynous myth of the divinity; Galit Hasan Rokem, Web of Life: Folklore and Midrash in Rabbinic Literature (trans. Batya Stein; Contraversions Series; Stanford: Stanford University Press, 2000) 128.

${ }^{4}$ It is unclear whether the various components of this proem were put together when the entire midrash was redacted, or how many would have circulated independently prior to their final redaction.

${ }^{5}$ On the structure of the proem as a "conflation of three separate sources," see David Stern, "Imitatio Hominis: Anthropomorphism and the Character(s) of God in Rabbinic Literature," Prooftexts 12 (1992) 151-74; idem, Midrash and Theory: Ancient Jewish Exegesis and Contemporary Literary Studies (Evanston, IL: Northwestern University Press, 1996) 80-87, who discerns two narratives, the first characterized by God's closeness to the destruction, the second one, by God's remoteness (p. 162). There are several distinct sections that the editor endeavored to connect, each headed by "another interpretation" or clearly distinct from its predecessor by the introduction of a specific sage, and all pondering the dramatic puzzle of how to instill shame in God. 
aspects of this proem stand out as both original and striking. ${ }^{6}$ One is the distinct dramatization of the scenes in which God is confronted by venerable patriarchs and prophets, a strategy that lends itself to the visualization of the proceedings as though performed on stage. ${ }^{7}$ Another is the sudden intrusion of a woman into a scene entirely dominated by males and the focus on the intimacy of her bed. As argued below, the theatrical genre of the mime, which in this period was far more popular than traditional comedy and tragedy, can illuminate the proceedings of LamR Pr. 24, and especially Rachel's scandalous autobiography. Mime actors were known for their outspokenness: they performed unmasked, mocked all ethnicities and religions, and spoke in everyday language and not the high-flown diction of other theatrical genres. Mime troupes included female performers: their presence was indeed crucial in the popular scenarios of adultery, where the plot hinged on the "adulteress" employing her wits to conceal a lover on the verge of discovery by an irate husband.

Our study sets out to demonstrate the debt of the midrashic confrontational dialogues to theatrical devices, particularly to those employed in mimes. It is our contention that by positioning a bed at the center stage of the final scene featuring a defiant female, the proem goes further than any other midrashic piece in echoing the perennially popular adultery mimes. We further contend that LamR $\operatorname{Pr} 24$ recasts the core of Christian martyrdom, namely, the will to sacrifice the self to get close (or closer) to the divine, by questioning the very meaning of martyrdom. How far does one have to go to reach the divine and to touch God's own heart? Martyrological narratives provide one sweeping answer; the midrash presents nuanced reflections.

This article highlights how the unique combination of rabbinic interpretation, stage drama, and the dramatic narratology characteristic of Christian martyrdom leads to a stunning tour de force (LamR Pr 24.23-24): the descent of a dea ex machina to the "underworld" of domesticity in an erotic agon waged with God himself. In what follows, we begin with an analysis of the text of LamR Pr. 24, drawing attention to its appropriation of theatrical devices and its relationships with contemporary visual imagery (mosaics) and texts from outside the rabbinic milieu (Christian Apocrypha). What emerges from this analysis is a far richer text than has so far been acknowledged. At the end of this first Part we turn to the figure of Rachel in the midrash and in contemporary liturgical poetry (piyyut). In Part $\mathrm{B}$ we examine the casting of midrashic Rachel as a response to both the mimic adulteress and the Christian martyr. Finally, we consider rabbinic familiarity with mime, particularly with its usefulness as a social mediator and agent of collective catharsis. It is precisely these aspects of mimic performance, we argue, that Rachel's vignette appropriates in this fascinating rabbinic text.

\footnotetext{
${ }^{6}$ On anthropomorphism in talmudic literature, see Yair Lorberbaum, In God's Image: Myth, Theology, and Law in Classical Judaism (Cambridge: Cambridge University Press, 2015) 13-43.

${ }^{7}$ Cf. Laura Lieber, "Setting the Stage: The Theatricality of Jewish Aramaic Poetry from Late Antiquity," JQR 104 (2014) 537-72, on piyyut — a genre that will also be discussed, briefly, below.
} 


\section{LamR Proem 24: A Theatrical Tour de Force}

\section{A. Prologue: Why the Cry? (LamR Pr 24.1-14)}

Proem 24, as it now stands, begins with a debate over the breadth and meaning of individual verses of Isaiah 22:1-14, a biblical inventory of the tragic scope of the destruction of the Judaean kingdom (586 BCE). In their late ancient midrashic context, the biblical verses evoke the more recent tragedies of the brutal suppression of two revolts against Rome ( 66 and $132 \mathrm{CE}$, respectively). ${ }^{8}$ The biblically recorded events, commemorated in the annual rituals of the Ninth of Av, belonged to sacred time outside history. By the fifth century CE, the Solomonic Temple may have been an old story. But the repetition, in current language, bridged the gap between myth and history. As it has been said of Athenian drama, "The contemporary material was used to lead the audience into the reality of the legend."

We first meet God as a character indulging in extravagant lamentation. ${ }^{10}$ Responding to the words of Isaiah 22:4 ("do not rush to console me"), Resh Lakish (third century) recruits the angels, as a chorus, to ponder the depth of the divine sorrow: "Said Resh Lakish: Only on three occasions when the ministering angels desired to deliver songs in front of God He did not allow them [to sing]. These were as follows: in the generation of the Flood, the generation of the sea, and the generation of the destruction of the Temple" (LamR Pr 24.9). ${ }^{11}$

Here, in a nutshell, is the rabbinic theology of catastrophe, which saw no reason to endow God with regret, since disaster was an inescapable outcome of Israel's sins against God and the Torah. ${ }^{12}$ Here, too, the stage is set for repeated attempts to sway the divine will, precisely as the biblical scroll of Lamentations does with its recounting of the horrors of $586 \mathrm{BCE}$. Hope, however, is always present. After

${ }^{8}$ Kimberley Christine Patton, Religion of the Gods: Ritual, Paradox, and Reflexivity (Oxford: Oxford University Press, 2009) 272-73, on rabbinic textual polysemy that reflects on the razing of the temple in $70 \mathrm{CE}$, while ostensibly discussing the biblical temple.

${ }^{9}$ The quote is from James Redfield, "Drama and Community: Aristophanes and Some of his Rivals," in Nothing to Do with Dionysos? Athenian Drama in Its Social Context (ed. John J. Winkler and Froma I. Zeitlin; Princeton: Princeton University Press, 1990) 314-35, at 326.

${ }^{10}$ The subject of lament and its ramifications has received considerable attention in recent years. For a systematic presentation, see Peter Kuhn, Gottes Trauer und Klage in der rabbinischen Überlieferung (Talmud und Midrasch) (AGJU 13; Leiden: Brill, 1978), with a catalogue of primary sources, each with its (German) translation; for a recent survey, see Keith Campbell, "NT Lament in Recent Research and Its Implications for American Evangelicals," JETS 57 (2014) 757-72.

${ }^{11}$ Note, too, the pun on the words "rush" תאיצו of Isa 22:4 and "blasphemy" נאוץ of Deut 14:11, 23 which deals with the generation condemned to die in the wilderness, the generation listed among the three events of failed angelic consolation.

${ }^{12}$ Cf. Alan Mintz, Hurban: Responses to Catastrophe in Hebrew Literature (Syracuse: Syracuse University Press, 1984); and David Kraemer, Responses to Suffering in Classical Rabbinic Literature (Oxford: Oxford University Press, 1995). Recently, Julia Watts Belser, Rabbinic Tales of Destruction: Gender, Sex, and Disability in the Ruins of Jerusalem (Oxford: Oxford University Press, 2018), argues for the replacement of God as the almighty agent of destruction and punishment with Rome. 
all, the first two catastrophes that generated an unstoppable pouring out of divine tears, on a universal and national scale, were followed by a double genesis, of the patriarchal clan and of collective Israel. The destruction of city and temple, already repeated, appeared irreversible. Is the same true for salvation? This is the premise that forges the thread of the plot.

According to Resh Lakish's presentation of the angelic pleading, the first two catastrophes, namely, the near annihilation of humankind and of Israel, were completed solely by divine design and agency. Not so the destruction of the temple, which had been wrought entirely by gentiles, as though chosen by God to punish God's chosen people. Should God, then, be accredited with the bitter realization of the enormity of this novel strategy? Were the chosen people destined to become martyrs on God's altar of revenge? ${ }^{13}$ In other words, was "martyrdom" the sole connection between himself and his battered people? If there was any hope of consolation and possible redemption, who among the biblical founders of the nation was capable of swaying the divine will, when God appeared so reluctant to cooperate?

This was neither idle theology nor speculative theory. The rabbis were not unaware of the centrality of martyrdom in the formation of Christianity, nor was martyrdom absent from Jewish annals under foreign rule. Both Jewish and preConstantinian Christian martyrdoms were presented as an unequal contest in which, contrary to expectations and conventions, the ostensibly weak yet ultra-pious invariably won. The rabbinic concept of martyrdom, as far as can be encapsulated in a single sentence, entailed death over sinning as the supreme expression not of sacrifice but of self-awareness. This is precisely the reason why the "martyrdoms" about to unfold on the stage of LamR Pr 24, each aspiring to possess the power to move God, were doomed to fail.

\section{B. Enter "Israel" and Metatron (LamR Pr 24.15-17)}

When the angels give up on trying to stop God from wallowing in misery, the community/collectivity of Israel (Keneset Israel, כנסת ישראל) appears, reminding God of the good old days, as though the specter of the glorious past when God dwelt in the temple would somehow restore both God to temple and people to land:

Now I am ashamed and humiliated. Even more she [Israel] added: Lord and Master of the Universe. My soul stoops whenever I pass by your home (i.e. the Temple), now ruined and steeped in silence. Only foxes dance on the very place where the seed of Abraham had made sacrifices to You, where the

${ }^{13}$ The subject of Jewish (and Christian) martyrdom in antiquity is exceptionally complex and controversial. See, among many, Daniel Boyarin, "Martyrdom and the Making of Christianity and Judaism," JECS 6 (1998) 577-627; and idem, Dying for God: Martyrdom and the Making of Christianity and Judaism (Figurae Series; Stanford: Stanford University Press, 1999) 67-92, on female attributes of maleness-martyrdom ideology. The place of LamR Pr 24, and indeed of other vignettes of LamR, in contemporary scholarly debates about martyrdom in antiquity requires a separate investigation. 
priests had stood on the platform and where the Levites had praised You with their violins. (LamR Pr 24.15)

Then, a punch line lays the blame not only on Israel alone but also on false prophets: "What can I do, I whose sins and false prophets diverted me from the path of life to that of death" (LamR Pr 24.15).

Seemingly inconclusive, the uneasy truce between God and Israel is subjected to an interpretation that casts a contrite God now in full cognition of the implications of the tragedy that his people had sustained:

Then the Holy One bitterly wept: Woe unto me! What have I done! I had lowered my Presence to dwell below for the sake of Israel and now that they have sinned I returned to my original dwelling place, where, heavens forbid, I have become an object of laughter in the eyes of gentiles and butt of universal mockery. (LamR Pr 24.17)

When both protagonists in the tearful drama, God and Israel, appear at a loss, the plot recruits Metatron (the mediator). Somewhat presumptuously, Metatron proposes to replace God by offering his own tears, as though their transfer from a weeping God to a lower being would erase the divine shame. ${ }^{14}$ By ancient standards, Metatron is behaving like a good, even obsequious, slave. His proposal of emotional surrogacy is designed to spare his master the unseemly loss of control that public weeping entails. ${ }^{15}$ As a gentlemanly slaveholder, God would be expected to transpose his shameful emotions and their bodily manifestations onto the surrogate bodies of his slaves. In one surviving mime script, this is precisely what takes place when an effeminate servant replaces his adulterous mistress in the hypocritical bewailing of the dead husband/master (see below). This act of comic mimicry unmasks the true emotions of the wife, who is rather relieved to become a widow. In LamR Pr 24, on the other hand, God the Master does not accept his "slave's" surrogacy. The rejection of Metatron is swift and crushing, yet also somewhat comic and petulant: "If you do not let me cry now, I will disappear into a place all but inaccessible to you to cry, as it is said: 'if you do not heed, my soul shall weep in secret places on account of your arrogance. (Jer 13:17)" " (Pr 24.17). God prefers to shed his own tears.

\footnotetext{
${ }^{14}$ Among many studies of this enigmatic figure, see Andrei A. Orlov, The Enoch-Metatron Tradition (Texts and Studies in Ancient Judaism 107; Tübingen: Mohr Siebeck, 2005) esp. 107-108 on our Metatron as an intercessor and a redeemer shouldering the sinners' transgressions; idem, Yahoel and Metatron: Aural Apocalypticism and the Origins of Early Jewish Mysticism (Texts and Studies in Ancient Judaism 169; Tübingen: Mohr Siebeck, 2017) 194; Nathaniel Deutsch, Guardians of the Gate: Angelic Vice-Regency in Late Antiquity (BSJS 22; Leiden: Brill, 1999) 76-77; Felicia Waldman, "Some Considerations of Enoch/Metatron in the Jewish Mystical Tradition," in In the Second Degree (ed. Alexander, Lange, and Pillinger) 205-18.

${ }^{15}$ Jennifer A. Glancy, Slavery in Early Christianity (Oxford: Oxford University Press, 2002) $10-15$, on slaves as surrogate bodies for the slaveholder.
} 


\section{Enter One Prophet and Four Patriarchs (LamR Pr 24.17 and the Apocryphal Acts of Andrew and Matthias)}

God suddenly seems to reclaim an active role. He recruits the ministering angels as companions on a heavenly excursion to Jerusalem, a tour of verification guided by Jeremiah, prophet of doom and gloom (and the author traditionally associated with the biblical Lamentations). The full realization of the extent of the disaster that had befallen Israel finally dawns, causing God to embark on a ritual of traditional lamentation as professional female chanters usually vocalized it (see below): "Where are you, my sons? Where are you, my priests? Where are you, my loyal followers? What shall I do in your case? I had warned you but you did not repent" (LamR Pr 24.17). God even confesses to Jeremiah that he, God, is like a father who lost his only son while standing under the canopy of his wedding, at the one moment that carried the promise of progeny and permanence.

Contrary to all predications, what follows is the meat of comic mime (which frequently showed confused and hurried comings and goings), featuring an energized God, a reluctant prophet, and mystified patriarchs. God entrusts Jeremiah with a curious mission:

(God): Go and call Abraham, Isaac, Jacob and Moses from their graves because they know how to weep.

(Jeremiah): I have no idea where Moses is buried.

(God): Go and stand on the bank of the Jordan river, raise your voice and shout: Son of Amram, son of Amram, stand up and look upon your flock which had been swallowed by the enemy.

Jeremiah instantly went to the cave of the Makhpela and told the fathers of the nation:

(Jeremiah): Stand up since the Lord demands that you come.

They said: Why?

(Jeremiah): I have no idea.

He was afraid lest the patriarchs say: In your days it happened to our descendants.

Jeremiah left them and stood on the banks of the Jordan shouting:

(Jeremiah) Son of Amram, son of Amram, stand up. You have been summoned to the Lord.

(Moses): Why now? What happened?

(Jeremiah): I have no clue.

Moses then went to the ministering angels whom he had known since the time that the Torah had been given [to Israel].

(Moses): Divine servants, do you know why I was summoned by the Lord? (Angels): Son of Amram, don't you know that the Temple had been destroyed, and Israel dispersed?

Moses then went away crying and shouting till he reached the fathers of the world who immediately tore their clothes, put their hands on their heads, likewise crying and shouting till they reached the very gates of the Temple. When the Lord saw them, a call immediately went out to pronounce the day 
a day of lament, of weeping, and of wearing sackcloth. It would have been impossible to describe how they cried and wept as they were walking from gate to gate like a man walking behind a coffin. (LamR Pr 24.17)

The rabbis' sense of mimic parody here is superbly matched by an apocryphal Christian text that employs the exact same theatrical technique, namely, to "resurrect" the venerable patriarchs, albeit not to join God in mourning but to prove Jesus's divinity to the Jews. The Acts of Andrew and Matthias (hereafter AAM), a text closely associated with the second-century Acts of Andrew ${ }^{16}$ engages Andrew and Jesus in a dialogue in which the latter, pretending to be a boat pilot, questions the former. At stake is the perennial matter of the Jewish rejection of Jesus's divinity (AAM 9-15). In the course of this interrogation, reminiscent of a comic dialogue in which one side is ignorant of the other's identity, Andrew "recalls" a scene at a pagan temple. According to Andrew, he was taken by Jesus on a tour of the sanctuary of the gentiles, built "in the form of heaven" (AAM 13), accompanied by a number of "disbelievers," including four "high" priests.

Arriving at the "sanctuary," Jesus points out two marble sphinxes that, he insists, resemble the heavenly cherubim and seraphim (AAM 13). ${ }^{17}$ At no point does the AAM specifically refer to the Jerusalemite Temple, but the postulated architectural milestones hint at a deliberate identification between sanctuaries sacred to polytheism and the sole center of Jewish worship in Jesus's time. Rabbinic circles were familiar with interpretations of the cherubim as "proof" of pluralistic Yahwism:

Rabbi Isaac launched (an interpretation of Jer 51:51: “we were put to shame, assailed by humiliation, clothed by disgrace, because foreigners/strangers have entered the Temple of the Lord"). You realize that when our enemies entered Jerusalem they were accompanied by Moabites and Ammonites, as it was said (Lam 1:10). They entered the Holy of Holies and found there two cherubim which they put in a cage (כליבה), marching these back and forth throughout the streets of Jerusalem, all the while proclaiming: Did you not boast of being a nation of non-idolaters? Look at what we discovered and at what they [really] worshipped! Behold-all faces are alike... Another

${ }^{16}$ The date is unclear, ranging between the 2 nd and the 5 th centuries, likely the former rather than the latter. See Dennis Ronald MacDonald, The Acts of Andrew and the Acts of Andrew and Matthias in the City of the Cannibals (Atlanta: Scholars Press, 1990) esp. 46-47, arguing that the text as a whole is earlier and was part of the original Acts of Andrew. The section here discussed is considered by some to be a later, 5th-cent. interpolation, a hypothesis that matches Buber's assumption of the late date of the Rachel section in LamR Pr 24, and equally difficult to prove. For a recent brief overview of the AAM, see Julia Snyder, "Akten des Andreas und Matthias in der Stadt der Anthropophagen," Bibellexicon (2016) https://www. bibelwissenschaft.de/stichwort/49860/.

${ }^{17}$ There is no agreement regarding the shape of the temple's cherubim, which, to an extent, may have resembled the famed Egyptian temple sculptures; see Manfred Krebernik, "The Beginnings of Yahwism from an Assyriological Perspective," in The Origins of Yahwism (ed. Jürgen van Oorschot and Markus Witte; BZAW 484; Berlin: de Gruyter, 2017) 45-66, at 56; Angelica Berlejung, "The Origins and Beginnings of the Worship of YHWH: The Iconographic Evidence," in Origins of Yahsism (ed. Oorschot and Witte) 67-92, at 85-86. 
interpretation: Shame and humiliation refer to [the fast] of the seventeenth of Tamuz; disgrace refers to the [fast] of the Ninth of Av ... [dates marking] the first and second destruction [of the Temple]. (LamR Pr 9) ${ }^{18}$

What happens next according to the AAM is a dramatic tour de force: Jesus commands one sphinx to come down from its platform in order to prove, presumably once and for all, that he is divine and not human. The sphinx indeed leaps up, assumes a human voice, and confirms that Jesus is the one "who called Abraham, who loved his son Isaac, who returned his beloved Jacob to his land." In a development that is clearly indebted to the Gospel of John (8:56-58), the "high" priests refuse to accept the claim that Jesus could have known Abraham, who died long before Jesus was born. At this point,

Jesus turned to the sphinx and said to it:

(Jesus): Why do these people not believe that I spoke with Abraham? Go to the land of Canaan, go to the double cave in the field of Mamre, where lies the body of Abraham. Stand outside his tomb and cry out: "Abraham, Abraham, you whose body is in the cave but whose soul is in paradise. This is what the one who molded humans at the beginning and who made you his friend says: Rise with your son Isaac and with Jacob, go into the temples of the Jebusites and refute their allegations. Let them know that you knew me and that I knew you."

Immediately the sphinx ... did just as Jesus had commanded it. At once the twelve patriarchs came out of their tomb, alive, and said to the sphinx:

(XII): To which of us were you sent?

(Sphinx): I was sent to the three patriarchs for evidence. As for you, go and stay put till the time of the resurrection.

Hearing this, they turned back to their tombs and fell asleep. The three patriarchs accompanied the sphinx, came to Jesus and refuted the high priests.

Then Jesus said to them:

(Jesus): Go back to your places.

They left at once. Jesus then turned to the sphinx and said:

(Jesus): Go back up to your platform.

Immediately it arose and stood at its place ... still, the high priests refused to trust Jesus's words. (AAM 14-15) ${ }^{19}$

The mission with which the sphinx is entrusted appears as startlingly original as Jeremiah's order to raise the same patriarchs from the dead..$^{20}$ Both accounts of

${ }^{18}$ Rachel Neis, The Sense of Sight in Rabbinic Culture: Jewish Ways of Seeing in Late Antiquity (Greek Culture in the Roman World; Cambridge: Cambridge University Press, 2013) 97-99, on this passage and its parallels in the Babylonian Talmud.

${ }_{19}$ Translation slightly adapted from J. K. Elliott, The Apocryphal New Testament: A Collection of Apocryphal Christian Literature in an English Translation (Oxford: Oxford University Press, 2005).

${ }^{20}$ One wonders whether the lost "historical drama," the Sphinx, of the grammaticus Ptolemy Chennus (late 1st/early 2 nd cent. CE), may be traced back to this astonishing imagery. It is unclear whether it was a novel or a comic drama. The same title was used for a comedy of Epicharmus and a satyr-play of Aeschylus. For a recent treatment of this intriguing author, see Beth Hartley, 
this selective resurrection are tinged with a touch of humor: in AAM, the sphinx apparently raises more patriarchs than necessary; in LamR Pr 24, Jeremiah plays the fool who has no idea how to fulfill his mission of resurrection.

The twelve patriarchs who willingly step out of their tombs at the behest of the sphinx - clearly a number harking back to the twelve apostles - seem either too eager or incapable of comprehending an ostensibly simple command. Nine are told by the (more authoritative!) sphinx to go immediately back to their place of rest, while the significant three are swiftly transported to the "trial," where they are expected to bear testimony on Jesus's behalf. Having carried out this duty they are summarily dispatched back to their tombs. AAM dwells neither on the journey nor the trial. What catches its attention is the comic juxtaposition of the entirely pagan sphinx with the entirely Jewish patriarchs - a revealing indication of the uneasy co-opting of Jewish history by the erstwhile gentiles turned Christian.

LamR Pr 24 allocates generous space to the patriarchs who are expected to join God as all indulge in uncontrollable lamentation. ${ }^{21}$ The theatricality of the scene is enhanced by the presentation of these foundational figures as ignorant of the past (past their own biblical time), as though they were cast as the proverbial stupidi of mime, men unaware of what is happening in their own home and under their own nose.

From the farcical search for Israel's ancestors to the gates of razed Jerusalem, the cavalcade reaches a cemetery where both the abode of God and Israel's hopes had been buried. The march, although uniting God, patriarchs, and prophet, opens a gap between the divine discourse of lamentation and the mortal language of mourning. ${ }^{22}$ The wind of desertion that has blown through the text so far is about to plunge God into a confrontation with Abraham, leading to one of the strangest trials in history and featuring a series of reluctant witnesses. As though scripted for a parodic mime on the intricate relations between divinities and their followers, the trial of the wayward Israel reveals misplaced expectations.

\section{The Heavenly Court: The First Witnesses (LamR Pr 24.18)}

Abraham mounts an investigation into the reasons for exile, destruction, and death that had been so savagely inflicted on God's people.

(Abraham): Lord of the Universe, why did you exile my children? Why did you hand them over to gentiles who killed them in all manners of brutal

\footnotetext{
"Novel Research: Fiction and Authority in Ptolemy Chennus" (PhD diss., University of Exeter, 2014) https://core.ac.uk/download/pdf/43093801.pdf. For another apocryphal New Testament text that incorporates scenes derived from street theater and mime, see the Acts of John, with discussion, by Eckhard Plümacher, "Paignion und Biberfabel. Zum literarischen und popularphilosophischen Hintergrund von Acta Iohannis 60f.48-54," Apocrypha 3 (1992) 69-110.

${ }^{21}$ Stern, "Imitatio Hominis," 160-61, for a different interpretation.

${ }^{22}$ A. Bielik-Robson, "The Unfallen Silence: Kinah and the Other Origin of Language," in Lament in Jewish Thought: Philosophical, Theological, and Literary Perspectives (ed. Ilit Ferber and Paula Schwebel; Perspectives on Jewish Texts and Contexts 2; Berlin: de Gruyter, 2014) 33-52.
} 
execution? Why did you destroy the Temple where I had sacrificed my son Isaac to you?

(God): Your descendants sinned. They transgressed every rule of the Torah, each of its twenty-two letters ... (Abraham): Who is your witness?

(God): Let the Torah come and give her testimony.

Immediately the Torah appeared to give testimony.

(Abraham): My daughter, you have come to provide testimony against Israel's transgressions of your rules. Are you not ashamed to do so in front of me? Remember the day when the Lord peddled you to every nation and in every language and none wanted to accept you until my children came to Mount Sinai, embraced you and respected you? And now you have come to testify against them in their hour of suffering?

When the Torah heard Abraham's [remonstrance] she stood aside and forbore to testify.

(God to Abraham): Let the twenty-two letters come and testify.

They immediately came. Aleph was ready to testify that Israel transgressed the Torah.

(Abraham): Aleph, you, head of all the letters, now you have come to testify against Israel in their dire hour? Remember the day when the Lord was revealed on Mount Sinai and opened his address with you: "I (אני) am the Lord your God" (Ex 20:2)? When no nation was willing to accept you other than my children? And now you have come to testify against them?

Immediately Aleph stood aside and forbore to bear testimony. Then Bet came. (Abraham): My daughter. Have you come to testify against my children who had been quick to adopt the Pentateuch that you launch, as it is said "In the beginning (בראשית) God created" (Gen 1:1)?

Then Gimmel.

(Abraham): Gimmel, you came to testify that my children transgressed the Torah. Is there anywhere a nation besides my children that fulfils the command of șisit (ציצית, "mantle fringes"; cf. gedilim) that were mandated (Deut 22:12)?

Immediately Gimmel stepped aside, maintaining silence.

When the rest of the letters of the alphabet realized that Abraham managed to silence the first three, they were ashamed and kept silent and did not testify against Israel.

This is an ingenious scene, a veritable burlesque in which God is alternately the prosecutor and the accused. The witnesses, challenged by God to lend substance to his position as plaintiff, are silenced one by one by a man whose very presence in the House of God is questioned by God. The presentation of the heavenly court as an arena in which the supreme judge himself is challenged by a self-appointed attorney on behalf of Israel seems nothing short of a satire based on earthly courts. ${ }^{23}$

${ }^{23}$ See Meira Z. Kensky, Trying Man, Trying God: The Divine Courtroom in Early Jewish and Christian Literature (WUNT 2/289; Tübingen: Mohr Siebeck, 2010) 293-340, on the employment of the courtroom as recapturing divine annals devised to fill gaps in Scripture, as well as an exploration of the divine "personality" itself. Especially interesting is the "doctrine of merit," wielded by the patriarchs as guarantee of the acquittal of accused Israel. Note the verb attached to the personification 
It also reflects familiarity with the type of school exercises that staged court cases. The very presence of personified letters as witnesses introduces more than a whiff of irony into the would-be trial. One could compare Lucian's Consonants at Law (second century CE, Syria), a speech to be delivered by the letter Sigma in a spoof trial against the letter Tau. ${ }^{24}$

The Torah and the alphabet, witnesses for the prosecution, provide proof that memory is layered and that God's constant insistence on Israel's recent violations erases, unjustly, Israel's mythic merits. ${ }^{25}$ In the next court scene, each of the summoned founding figures pleads his specific merit, as though to prove God entirely wrong: not only does Israel collectively deserve credit for countless moments of demonstrative piety, but the individuals responsible for birthing the nation likewise are outstanding examples of commitment to God.

\section{E. The Heavenly Court: Patriarchal Pleas (LamR Pr 24)}

Abraham, Isaac, Jacob, and Moses now delve into their personal histories in search of evidence that they suffered enough to deserve God's mercy.

Immediately Abraham addressed God as follows:

(Abraham): Lord of the Universe. When I turned one hundred you gave me a son. When he acquired understanding at the age of thirty-seven, you told me to sacrifice him to you. I was cruel, did not spare him, and with my own hands I tied him. Will you forbear to recall this and to take pity on my children?

(Isaac): Lord of the Universe. When father told me: "God will show the lamb to be sacrificed" (Gen 22:8), I did not doubt your word and willingly gave myself to die on the altar, stretching my neck under the knife. Will you not

of accusation (קטגוריה qategoriyah) in LamR 1.41 who springs up (קפצה qaș) before God (p. 320). This is the verb that LamR Pr 24 attaches to Rachel's intervention in the proceeds of the heavenly court. On divine trial scenes, see also Chaya Halberstam, "Justice without Judgment: Pure Procedural Justice and the Divine Courtroom in Sifre Deuteronomy," and Dov Weiss, "Lawsuits against God in Rabbinic Literature," both in The Divine Courtroom in Comparative Perspective (ed. Ari Mermelstein and Shalom E. Holtz; BibInt 132; Leiden: Brill, 2015) 49-68 and 276-88, respectively. See also Nicholas Jameson Ellis, The Hermeneutics of Divine Testing: Cosmic Trials and Biblical Interpretation in the Epistle of James and Other Jewish Literature (WUNT 2/396; Tübingen: Mohr Siebeck, 2015). For trial scenes in both rabbinic texts and Christian martyrologies and how they reflect Roman practices and institutions, see the classic study of Saul Lieberman, "Roman Legal Institutions in Early Rabbinics and in the Acta Martyrum," JQR 35 (1944) 1-57.

24 "Mr. Tau" has been trespassing and encroaching on "Mr. Sigma's" territory (i.e., taking over his place in certain words), leading Sigma to express fears that he might be "struck dumb" and "lose his rank as a letter" (2). Lucian was both a great satirist and a fierce apologist for theatrical mimesis; see his defense of the pantomime in On the Dance (De saltatione).

${ }^{25}$ See Adam Gregerman, Building on the Ruins of the Temple: Apologetics and Polemics in Early Christianity and Rabbinic Judaism (Texts and Studies in Ancient Judaism 165; Tübingen: Mohr Siebeck, 2016) 162-66, on this section as a trial, with God as judge, Abraham as defense attorney, Israel as defendant, and the Torah and the alphabet as witnesses. But the "trial" is somewhat absurd, as punishment has already been meted out; ibid., 182-84, on God's responsibility for loss and failure. 
remember this for my sake and spare my children?

Then Jacob spoke.

(Jacob): Lord of the universe, for twenty years I toiled in Laban's house and when I finally left it [to return home] the wicked Esau met me seeking to kill my sons. I was ready to die for their sake. Yet you handed them over to their enemy like lambs to slaughter after I had toiled so to raise them? I suffered greatly to bring them up and now you will not remember this and take pity on them?

Moses then said:

(Moses): Lord of the Universe, was I not a faithful shepherd of Israel for forty years? .. . And now that they are exiled you sent for me so that I may lament and cry over them? Is this what the proverb means: "when it is good for the master it is not good for me, and when it is bad for the master it is really bad for me"? (LamR Pr 24:18)

In this reconstructed drama, pleading the past, particularly one's own martyrdom, turns out to be little more than word play, a valiant if vain attempt. We may perceive the entire sequence of the "trial" as a comic liturgy, conducted in tandem by God and Abraham. We know from the beginning that God has doubts about Abraham's sudden appearance, conveniently "forgetting" that he had entrusted Jeremiah with summoning the patriarch. Notwithstanding the successful silencing of God's favorite witnesses, the Torah and the alphabet, spectators may guess, correctly, that God will not be moved. This is, in fact, the entire point of this mimic liturgy. It is a production within a closed circuit. God's chosen "lover," Abraham, remains firmly grounded in a representation of the helpless human species.

Patriarchal claims of "martyrdom" are greeted with stony silence. This, too, seems contrary to expectations. Who would have anticipated that Abraham, Isaac, Jacob, and Moses would fail the test of true martyrdom to become the butt of divine disdain $?^{26}$ The winds of desertion that engulfed valuable witnesses during the trial make a mockery of the assumed nobility of patriarchal sacrifices. We may recall the lamenting shrill of the murderous mimic adulteress whose pretense is obvious to both spectators and to the seemingly dead victims. Hypocrisy reigns supreme in the character of the adulteress; repeated claims to martyrdom ring hollow. ${ }^{27}$

Moses's testimony against God ends in a proverb that turns the former into a slave: "My master's good fortune is not good for me, but his bad fortune is bad for me." Like a slave, Moses is called upon to suffer and lament when catastrophe strikes, even though he had no share in the happier times - his bones buried in the desert just before the nation's return from the earlier exile.

Exasperated, Moses asks Jeremiah to lead him into Babylon, whence he hopes to gather the Jews and lead them back to their land. Moses aspires to a repetition of

${ }^{26}$ This is precisely the statement of the mother in LamR 1.50 who witnesses the brutal martyrdom of her seven sons, and who challenges Abraham to match the colossal scale of her sacrifice and of that of her children. On this passage, see ibid., 185.

${ }^{27}$ See below for the mock contest on who can sing better the dirge for the supposedly dead master. 
his biblical miracle - and also to a mimic scenario. For mimes also portrayed the rescue of captives from faraway, exotic countries. In the Charition mime (below), the mission ends with the successful escape of the brave rescuer, his captive sister, and his sidekick from the violent kingdom of India. In the midrash, even though the roads are strewn with corpses, Moses and his reluctant sidekick, Jeremiah, manage to reach Babylon. The happy end is in sight. But just as the much-relieved Jews are about to be rescued, a heavenly voice calls out, "The exile has been decreed by me!" The sudden and irrevocable conclusion to Moses's adventure "abroad" comes from God himself. Moses has to abandon his people and leave Babylon all alone (even Jeremiah is forgotten at this point). He is reunited with the patriarchs in what soon turns into yet another collective dirge.

\section{F. Helios, Synagogue Mosaics, and a Touch of Vernacular (The Aramaic LamR $\operatorname{Pr} 24.20-22)$}

The plot reaches, once again, a stalemate, but this time in Aramaic and not in Hebrew, as though the script seeks to forge an even more immediate connection with audiences in their own daily language. This is a curious shift from the language of ritual to which synagogue audiences in late ancient Palestine would have been accustomed. The spread of piyyut further bolstered the exclusive context of the "holy language," intimately familiar to members of rabbinic circles. LamR Pr 24 unfolded, for the most part, in the language intimately linked with the biblical characters that it harnesses. The brief appearance of the decidedly nonbiblical Helios (the sun) evidently called for the use of the vernacular.

In his desperation, Moses turns to the sun and curses him: "You are accursed, O sun! Why did you not darken when the enemy entered the Temple?" Somewhat unexpectedly, the sun actually replies. His explanation is perhaps as odd as the very fact he speaks: “How could I turn dark? They wouldn't let me! They wouldn't leave me alone! They lashed me with sixty whips of fire and said to me, Go forth and shine!" How are we to imagine this living, breathing, speaking sun? The zodiac cycle mosaics found in late ancient synagogues across Palestine are a strong indication that this anthropomorphic sun is the literary manifestation of a GrecoRoman-style Helios, portrayed in the mosaics as a charioteer wearing a crown of solar rays. ${ }^{28}$ The question, "What is Helios doing here?" has frequently been posed for the zodiac mosaics (but never for the midrash). Answers have focused on a mystical, nonrabbinic form of Judaism and on the rise of the priestly class, which, unlike the literally minded, puritanical rabbis, controlled the synagogues. ${ }^{29}$ Another

\footnotetext{
${ }^{28}$ For an overview, see Stephen Fine, Art and Judaism in the Greco-Roman World: Toward a New Jewish Archaeology (Cambridge: Cambridge University Press, 2005) 198-207.

${ }^{29}$ This interpretation was first put forward by Erwin Ramsdell Goodenough, Jewish Symbols in the Greco-Roman Period (Abridged Edition) (ed. Jacob Neusner; Princeton: Princeton University Press, 1988) 11 and 21-22. The excellent analysis of Jodi Magness, "Heaven on Earth: Helios and the Zodiac Cycle in Ancient Palestinian Synagogues," DOP 59 (2005) 1-52, presents a more sophisticated version of the same argument.
} 
interpretation, not incompatible with the first, sees the Helios of the mosaics as possibly identifiable with Metatron, the divine intercessor and, in mystical texts, a second, lesser God. ${ }^{30}$ In this view, Metatron's similarities with Christ may have increased his appeal among laypeople (hence his presence as Helios in the mosaics), while simultaneously putting the rabbis on their guard against the archangel, as they would be wary of his possible divinization. Accordingly, rabbinic sources demote Metatron, most famously when he is mistaken for a second divinity by a heretic who visits the heavens, and, in order to prove this assumption wrong, the archangel is "beaten with sixty lashes of fire" (b. Hag. 15a).

In LamR Pr 24 "Helios" receives the exact same treatment as the Metatron of the Babylonian Talmud. The possibility of an identification between the two gains ground. The appearance of Metatron himself earlier in the proem and his downgrading by God, who refuses his services, points in the same direction. Both "Helios" and Metatron are treated like slaves (essential cast members in almost all mime scenarios). Both are, in fact, venerable figures of notable popularity. If Metatron was the "Christ" in at least some Jewish circles, Helios was a familiar figure in mimes and a god of imperial clout. ${ }^{31} \mathrm{~A}$ papyrus fragment (first/early second century CE) transmitting a mime's prologue recruits the Sun god to proclaim a new era with the ascent of Trajan to the imperial throne..$^{32}$ Another papyrus, P.Berol. 13927, which preserves an inventory of props required for mime performances, lists as the only requirement for a play titled "The One of the Sun" the sunbeams that would decorate the actor's crown. ${ }^{33}$ Helios's appearance in mime plays could also have something to do with his proverbial role as "all-seeing" - he is the ideal, and frequently only, witness to adultery. ${ }^{34}$ LamR Pr 24 takes this trait and turns it on its head. This sun does not want to witness and refuses to shine. Like a slave, or like the mimic Diana mentioned by Tertullian (Apologeticum 15, on which below), he is flogged. The fiery god is lashed with fire. His punishment is both ridiculous and cruel. It demotes him, but at the same time it reveals God as the merciless master of a household where there can be no secrets and no crime can go unnoticed or unpunished. How could one ever hope to stand up and speak with impunity against such a divinity?

${ }^{30}$ Magness, "Heaven on Earth," 30-48.

${ }^{31}$ The Sun god, in the guise of Sol Invictus, was used to represent the Roman emperor; the Helios on the mosaic of Hammath Tiberias belongs to this type; ibid., 31 .

${ }^{32}$ P.Giss I. 3-also edited as Fr. 5 by Ian Campbell Cunningham, Herodae Mimiambi cum Appendice Fragmentorum Mimorum Papyraceorum (BSGRT; Leipzig: Teubner, 1987).

${ }^{33}$ See Serena Perrone, "Back to the Backstage: The Papyrus P.Berol. 13927," Trends in Classics 3 (2011) 126-53, at 138.

${ }^{34}$ Helios already has this role in the burlesque tale of divine adultery between Ares and Aphrodite, sung by Demodocus in Odyssey 8.266-369. 


\section{G. Dea ex Machina (LamR Pr 24.23-24)}

It is at this impasse that, like a dea ex machina, Rachel is introduced (and the script reverts to Hebrew).

(Moses to God): You continue to maintain your silence.

At that point Rachel our mother jumped in front of the One Blessed be He, saying:

"Lord of the Universe, it is known to you that Jacob your servant loved me very much and toiled for me for seven years in my father's house and that when these seven years were complete my father planned to substitute my sister for me as a wife. I knew his plan and therefore was cast into a dilemma. I informed my husband [of my father's plot] and gave him a sign to distinguish between me and my sister. But later I had a change of heart. I suppressed my desire [for Jacob] and conceived pity for my sister's shame.

In the evening, when my sister was substituted for myself, I disclosed to my sister the signs I had given to my husband so that he would believe her to be me. I even crawled under their bed. When he talked to her she maintained her silence while I answered him lest he recognized her voice. I did her kindness. Nor was I envious of her or exposed her shame. And if I, a mere mortal, dust and ashes, overcame my envy and did not shame my sister, why should You, the merciful King, be jealous of idolatry that has no substance and exile my children to be put to death by the sword and to become a prey to their enemies?"

And immediately the mercy of the Lord was stirred and He said: "For you, Rachel, I will restore Israel to her place." For it was said (Jer 31:15): "A voice is heard in Ramah. . . . Rachel is weeping for her children." (LamR Pr $24.23-24)^{35}$

Genesis is back in the picture, but the patriarchs are gone. Instead, a human triangle is on the stage, one man and two women, a seemingly perfect cast for an adultery mime. By bedding Leah, Jacob becomes somewhat analogous to an adulterer. The original agreement with the bride's father specifically referred to Rachel, the younger sister. ${ }^{36}$ Rachel herself refers to Jacob as "my husband" throughout her confession. But in Laban's territory, older daughters must be married off before younger daughters, as Rachel tacitly acknowledges. She is torn between two poles of loyalty, to father and to husband. Her choice presents a stunning coup. How can this demonstration of "martyrdom" succeed when patriarchal models had failed? Who, exactly, is analogous to an adulterer-character in the charade?

Keeping to an all-female domain, Rachel's gesture forges a strong connection between comedy and religion. In the mime that Rachel performs, there is room for seducing the divine. Rather than harping on the past, Rachel intimates a future when she and Jacob will be finally united in matrimony. Until that longed-for moment, Rachel subjects eroticism to pity and shame. Her "autobiography" in LamR Pr 24

\footnotetext{
${ }^{35} \mathrm{We}$ will address the sexual surrogacy in this passage and its parallels in a separate article.

${ }^{36}$ As stated by the 3rd-cent. Roman jurist Ulpian, "not intercourse, but agreement creates a marriage" (Dig. 50.17.30: nuptias non concubitus, sed consensus facit).
} 
is studded with terminology ordinarily applied to God. Unlike God, she overcomes jealousy, dispenses charity, and understands disgrace. By a bold exegetical move LamR Pr 24 gambles on Rachel, a woman who never experienced widowhood. Martyrdom acquires a new and radicalized meaning. It is not a retreat unto death, as Christianity asserted, but a journey into self-awareness of what makes a human human.

In this final scene of the proem-nearly a burlesque - the indifferent divinity is brought to heel by the weakest of Israel's defenders, a woman whose main merit, according to Jeremiah, was her ability to mourn. God can easily afford to be magnanimous toward her without losing face. With her, the memory of the love that once infused the relationship between God and Israel (Jacob) resurfaces. Accusing God of impiety, Rachel accomplishes the impossible. She, like God, had a choice. Underlying her speech is an assumption of temperamental affinity. Sparing Leah reminds God that it is possible to show mercy precisely by a show of weakness rather than of strength.

The originality of this parodic midrash can be seen more clearly if we compare it to synagogal ritual poetry (piyyut), where similar scenes are vocalized to dramatically different effect. ${ }^{37}$ Two piyyutim, originally two sections of a larger poem, a Qerova composed by Kallir (late sixth/early seventh century) for the Ninth of Av, the day marking the destruction of both temples, patently respond to LamR, the mandatory biblical reading of the same day. Neither poem betrays the slightest hint of parody. The "first" piyyut is scripted as an encounter between the grieving Jeremiah and a female figure who is never quite identified. ${ }^{38}$ The prophet calls on his interlocutor to cease her wayward ways; she urges him to plead her cause directly to God, but God in turn prefers to send Jeremiah to recruit the patriarchs to serve on an appealing chorus of lamentations, precisely as God had done in LamR Pr 24:

Get going, Jeremiah. Why are you silent?

Go and call the patriarchs, and Aaron and Moses

Let the shepherds come and raise a dirge

For the desert wolves devoured their lamb. ${ }^{39}$

${ }^{37}$ This connection has already been forged in Menahem Zulay, "An Ancient Poem and the Petihot of 'Eykah Rabbati," Tarbiz 16 (1944-45) 190-95 (Hebrew).

${ }^{38}$ Both Lieber and Novick (see n. 39) name her "Lady Zion." We believe that her identity is deliberately elusive, left to the audience to determine.

${ }^{39}$ The Hebrew text is in Daniel Goldschmidt, Qinot for the Ninth of Av according to the Tradition of the Polish and Ashkenazic Communities in Israel (Jerusalem: Mosad ha-Rav Kook, 1968) 101-2 (Hebrew); also available online at Ma'agar Happiyyutim, http://old.piyut.org.il/textual/743.html. The text of both of Kallir's piyyutim is reproduced with English translation and commentary, including parallels with Pesiqta Rabbati 26, in Tzvi Novick, "Between First-Century Apocalyptic and SeventhCentury Liturgy: On 4 Ezra, 2 Baruch, and Qillir," JSJ 44 (2013) 356-78, at 370-72; T. Carmi, The Penguin Book of Hebrew Verse (New York: Penguin, 1981) 224-26. An English translation and commentary are also provided in Laura Lieber, "Theater of the Holy: Performative Elements of Late Ancient Hymnography," HTR 108 (2015) 327-55, at 350-51. 
The poem ends on this tragic note of a stalemate that leaves all parties helpless to alter the situation. Its "continuation" resumes with Jeremiah addressing the patriarchs at their tomb, prodding them to wake up from their sleep to the bitter reality of the fate of their descendants. ${ }^{40}$ Plot, progression, and pleadings hinge on a double refrain that runs throughout the poem, spoken alternately by the patriarchs and by God: (the patriarchs) "If, as is only too human, they violated the covenant, where is the merit of the ancestors with whom that covenant had been effected?" ${ }^{1}$ (God) "What can I do, my children? This is the decree issued by me."

Four biblical females bring the chorus of patriarchal pleading to its apogee: the penultimate stanza marshals Leah, Rachel, Zilpah, and Bilhah:

The sound of Leah's banging her breasts,

her sister Rachel bewailing her sons,

Zilpah beating her face

Bilha blubbering as she gestures with both arms. ${ }^{42}$

The imagery of this stanza is taken straight out of the trappings of funerals where professional female mourners (מקוננות) performed the graveside ritual of keening: their grief, loud and emotional, was displayed in beating the chest, hand wringing, and chanting dirges (qinot). ${ }^{43}$ None among Kallir's synagogal audience would have missed these allusions to contemporary practices. Having extolled an allmale genealogy of patriarchs and prophets, the poet's selection of female figures is striking. Instead of the traditional matriarchs (Sarah, Rebekah, Leah, Rachel), Kallir delves into the intimacy of Jacob's bed, not via Rachel's account as does LamR Pr 24, but by grouping the four bedmates around a bier. ${ }^{44}$

${ }^{40}$ Text and translation in Novick, "Between First-Century Apocalyptic," 373-78; text and translation are also available online, https://sites.google.com/site/rebbarn1/kinnot26 (Hebrew) and https://opensiddur.org/prayers/lunar-cycle/commemorative-days/fast-days/tisha-bav/az-bahalokhyirmiyahu-kalir-c-7th-cent (Hebrew and English).

41 "The merit of the ancestors" or ancestral merit — in other words, the marshaling of the actions that deserve divine recognition in the hope of incurring divine assistance for their descendants - is a well-known theme in the history of communications between God and Israel. See Uri Ehrlich, "The Ancestors' Prayer for the Salvation of Israel in Early Rabbinic Thought," in Jewish and Christian Liturgy and Worship: New Insights into Its History and Interaction (ed. Albert Gerhards and Clemens Leonhard; Jewish and Christian Perspectives 15; Leiden: Brill, 2007) 249-56, esp. 252-56 on the addition of Rachel (Gen. Rab. 82.10) to the pleading patriarchs (and below); Kuhn, Gottes Trauer, esp. 219-39 on Rachel (and below); Christine Ritter, Rachels Klage im antiken Judentum und frühen Christentum. Eine auslegungsgeschichtliche Studie (AGJU 52; Leiden: Brill, 2003) esp. 191-94. For additional bibliography, see Sarit Kattan Gribetz, "Zekhut Imahot: Mothers, Fathers, and Ancestral Merit in Rabbinic Sources," JSJ 49 (2018) 263-96, and below.

${ }^{42}$ No translation can convey the striking word game of the stanza, with its rhyming ending of each line (her heart-her sons - her face-her hands). We did attempt to convey the deliberately chosen verbs, each beginning with the same letter (mem) in the original (metofefet, mebakkah, makkah, meqonenet $=$ banging, bewailing, beating, blubbering).

${ }^{43}$ Rachel Hakhlili, Jewish Funerary Customs, Practices and Rites in the Second Temple Period (Supplements to the Journal for the Study of Judaism 94; Leiden: Brill, 2005) 326-27; cf. Gail HolstWarhaft, Dangerous Voices: Women's Laments and Greek Literature (London: Routledge, 1992).

${ }^{44}$ The unusual female quartet may owe its roots to an old tradition that counted Bilha and Zilpa 
The four women are not allowed to deliver a personal plea based on their singular "merit," as do their male counterparts. Their participation highlights the poetic mood of despondency. A sense of chaos is further reflected in the role reversal of the women, with Leah as the chief weeping agent, in spite of the famed verse from Jeremiah (31:15) that forever etched the image of the inconsolable Rachel in Jewish annals..$^{45}$ As though further to emphasize Rachel's secondary place in the poem, Kallir, exceptionally, states her relationship to Leah.

Kallir's poems were written specifically for the ceremonies commemorating the Ninth of Av, a day marking the destruction of both temples (as well as other disasters in Jewish history). The presence of Jacob's female partners, here in the exclusive role of funerary accompaniments, serves as a rebuttal of the midrashic elevation of Rachel. Kallir's audience, appreciative of the funerary immediacy of female voices and gestures, preferred to retain the gender imbalance even at the moment of striking patriarchal helplessness. Yet, it is only as a response to the voices of the four women that God finally relents:

Return to your rest, you the pure,

I will fulfill all your requests.

Kallir groups Rachel with Jacob's harem, careful to claim credit for all four women. His poetry may have reflected one side of Rachel's contested figure, particularly opposition to her remarkable elevation as the mother of collective sorrow/mourning in Jer 31:15-16. Yet, even before Kallir's "demotion" of Rachel, the Targum Jeremiah (TJ), a fourth-century Aramaic "translation" of the Hebrew, excised her altogether. ${ }^{46}$ She is not named in the translation of Jer 31:15, where the TJ employs instead the female pronoun. Moreover, the TJ "mistranslates" Rachel's "wages of your labor" (Jer 31:15) in favor of a reference to the "wages of your righteous fathers."

Why do Kallir and TJ deprive Rachel of the place she occupies in Jer 31:14-15 and, indeed, in LamR Pr 24? Is it because the dramaturgy of the midrashic narrative, so redolent of elements employed in both contemporary narratives of Christian martyrdom and comic mime, sat uneasily with rabbinic approaches to the perennial problem of $\sin$ and exemplary punishment versus exemplary sacrifice and reward? ${ }^{47}$

as Laban's daughters by a concubine, and hence half-sisters of Rachel and Leah: Jubilees 28.9; T. Naph. 1.9, 11; Gen. Rab. 74.13; Pirqe R. El. 36.3, with Robert Hayward, The Targum of Jeremiah (ArBib 12; Wilmington, DE: Glazier, 1987) 210.

${ }^{45}$ Could it be a "response" to the appropriation of the verse in Matt 2.18, where it is used in the context of the Herodian massacre of the children?

${ }^{46}$ Among scholarly discussions, see Tzvi Novick, "Wages from God: The Dynamics of a Biblical Metaphor," $C B Q 73$ (2011) 708-22, esp. 713 on the promise of wages as a key to future solace and on Rachel's distress as the "labor" for which she is entitled "wages," noting that children represent wages par excellence. See Ritter, Rachels Klage, 57-75, on Rachel in various ancient translations of Jer 31:15-17. On the date of Targum Jeremiah, see Hayward, The Targum.

${ }^{47}$ Nathan Eubank, Wages of Cross-bearing and Debt of Sin: The Economy of Heaven in Matthew's Gospel (Berlin: de Gruyter, 2013) 39-43, for a brief overview. 
Part B, below, investigates the contexts that informed both the composition and reception of LamR Pr 24: the mime performances that were a staple of city life in late antiquity; the dramatic visualization of Christian martyrdom; the trope of the mime-turned-martyr; and the relationship between mime and midrash.

\section{Theo-Drama in Late Antiquity ${ }^{48}$}

\section{A. LamR $\operatorname{Pr} 24$ and/as Mime}

LamR Pr 24, likely a sermon, would have been delivered on the Ninth of Av of each year in the course of synagogue rituals that marked this day on the Jewish calendar. ${ }^{49}$ At the core of Rachel's autobiography in LamR Pr 24 is an act commonly associated with mime actors, termed biologoi ("those who represent life"), whose role was to present a performance about domestic life that was both everyday and scandalous, shameful yet celebratory. Rachel's strategy is equally straightforward and yet startling. She projects two spheres around the same marital bed, a visible space above, which unites her intended husband Jacob with her older sister Leah, and an audible space below, whence her own voice lends authenticity to the proceedings.

As we contemplate midrashic Rachel under the bed we may laugh at a scene that is strikingly reminiscent of the conventional staging of adultery in GrecoRoman mime (a lowly and badly preserved genre) and in literature that clearly communicates with this mimic tradition. ${ }^{50}$ We may recall the famed tale from Apuleius's Roman novel Metamorphoses (second century CE) in which a woman hides a lover in a jar and proceeds to convince her husband, who suddenly appears, that the lover is a potential purchaser of the jar, merely engaged in checking the merchandise from within, so to speak. She even prevails upon her gullible spouse to peruse the jar in a similar manner, an interlude that enables her to carry on with her lover. ${ }^{51}$ Or we may envision in another Roman novel, Petronius's Satyricon (first century CE) the much-desired youth hidden under the bed of his lover, his

${ }^{48}$ Echoing Hans Urs von Balthasar's Theo-Drama: Theological Dramatic Theory (trans. Graham Harrison; 5 vols.; San Francisco: Ignatius Press, 1988-1998).

${ }^{49}$ We know very little about the readings conducted on this day beyond the biblical scroll of Lamentations or about the qinot delivered. See Michael Rand, "Observations on the Relationship between JPA Poetry and the Hebrew Piyyut Tradition: The Case of the Kinot," in Jewish and Christian Liturgy (ed. Gerhards and Leonhard) 127-44; Benjamin Elizur, "From Catastrophe to Consolation: Early Reading and Haftarah Practices on Saturdays of Poranut and Nehama and on Tisha B'Av," Derek 'Aggadah 12 (2003) 267-82, esp. 276-78 (Hebrew).

${ }^{50}$ See Ioannis Konstantakos, "Aesop Adulterer and Trickster: A Study of Vita Aesopi ch. 75-76," Athenaeum 94 (2006) 563-600, on the existence, side by side, of both literary and stage-drama adultery stories. Cf. Elaine Fantham, "Mime: The Missing Link in Roman Literary History," CW 82 (1989) 153-63.

${ }^{51}$ See Apuleius, Metam. 9.5-7, with Stephen Harrison, "Literary Texture in the AdulteryTales of Apuleius, Metamorphoses Book 9," in Desultoria Scientia: Genre in Apuleius' Metamorphoses and Related Texts (ed. Ruurd R. Nauta; Caeculus 5; Leuven: Peeters, 2006) 19-31, for connections with the adultery mime. 
presence betrayed by the simple act of thrice sneezing. ${ }^{52}$ Hiding, one surmises, could fill audiences with amusement but carried its own snares, some comic, a few tragic, and all endlessly dramatic. ${ }^{53}$

A midrashic bed, a mimic jar, and a stage bed simultaneously conceal and reveal. Yet the rabbinic tale defies conventions, folkloristic, gender, social, and credal. Having planted the husband's potential, indeed, desired lover, under his bed, while ostensibly concealing the identity of the female body in the bed, the tragicomic situation in the midrash morphs into a stunning confrontation. The constructed clash of the midrash is not between a spurned husband and wayward wife, as conventions have dictated for centuries. It is, rather, between a thwarted would-be wife and the divinity who should have taken her side. In Genesis, Yahweh had failed to do just that, compromising Rachel even further by blighting her with barrenness.

Midrashic Rachel under the bed, a wistful virgin, becomes the underpinning of the colossal cost of the destruction and dispersion that LamR elaborates throughout. Her presence in ostensibly so comic a position emphasizes not the temporary plight of the proverbial lover of adultery mimes but the permanence of Jewish martyrdom. Rachel represents the type of subversive ideology articulated in plots that cast martyrdom, Jewish and Christian, as a fable in which the meek martyr mocks the apparent limitless strength of her/his persecutors. She crawls under the bed, where she stages her ultimate emergence as the central character in a plot delineating the ordeal of martyrdom as one's complete subjugation to the divine voice in the self. Yet here, too, the rabbinic Rachel poses a puzzle. She is not an imitator of an unattainable model, as martyrs were of Christ. ${ }^{54}$ Rather, she dictates the mode of correct behavior to the ultimate authority itself, God. ${ }^{55}$

In order to understand the subtle ways in which the rabbinic text appropriates and reformulates the dramatic narratology of Christian martyrdom, the following two sections take a look at the relationship between mimes, martyrs, and the divine. Our analysis suggests that, for the contemporary audience of LamR, gods could be involved in mimes and mime actors could turn into martyrs. The Rachel of LamR $\operatorname{Pr} 24$ is not an altogether unparalleled figure, nor is this text alone in imagining

${ }^{52}$ See Petronius, Sat. 91, with Costas Panayotakis, Theatrum Arbitri: Theatrical Elements in the Satyrica of Petronius (Mnemosyne Supplementum 146; Leiden: Brill, 1995) 122-35, for detailed analysis.

${ }^{53}$ The higher-brow genre of comedy does not preserve any such scenario featuring a hidden lover. Perhaps the closest parallel in comedy is Plautus's Casina, where the clever wife thwarts her wayward husband's plan to sleep with their young slave Casina by replacing her with a male slave in the dark room where the affair would take place. The husband gropes around in the dark and is shocked to find a man rather than a girl; he is humiliated, and no adultery takes place. The wedding song punning on the name "Leah" and hinting at Jacob's real bedfellow as reported in Gen. Rab. 70.19 probably engages with a similar tradition of theatrical burlesque.

${ }^{54}$ On the mimetic relationship between the martyr and Christ, see Candida R. Moss, The Other Christs: Imitating Jesus in Ancient Christian Ideologies of Martyrdom (Oxford: Oxford University Press, 2010).

${ }^{55}$ See Stern, "Imitatio Hominis," 163-64. 
a mime scenario where mockery is serious and the mimic charade is interwoven with martyrdom.

\section{B. Martyrdom and Mime}

The genre of martyrology is indebted to, and resonates with, theatrical traditions: "trials," tragic (or indeed, comic) reversals, and concealed identities bridge the distance between the heroic martyr and the, often laughable, mime performer. Indeed, the two can sometimes coincide. According to the story attached to the martyrdom of a former actor named Philemon, a handsome bribe offered by a local deacon named Apollonius moved the pagan performer to engage in a public ruse. ${ }^{56}$ The story takes place in the Egyptian city of Antinoopolis during the Diocletianic persecution (end third/beginning fourth century CE). Philemon, formerly a mime actor and now a flute player, is apparently the city's favorite performer. The deacon Apollonius is evidently too fearful to die for his faith. Philemon is recruited to don Apollonius's outfit (pallium) and to offer a sacrifice in his place. ${ }^{57}$ That the former actor readily agrees is hardly surprising. After all, assuming others' identities was germane to his old profession. Even though the end, martyrdom for both performer and deacon, was predictable, Philemon's road from the stage to his grim end was paved with astonishing twists and turns.

In the course of preparing for the required sacrifice to prove his loyalty to the emperor and the gods of the empire, Philemon experiences a change of heart induced by no less than the Holy Spirit. He refuses to sacrifice. An altercation follows between the judge, who believes that he is dealing with Apollonius, and Philemon who is acting as the deacon. When the judge orders that Philemon be brought to him, the flute player naturally cannot be found. Instead, his brother Theonas is produced. Correct identities established, the judge is convinced that the entire plot was a charade, but he still insists that the due sacrifice be performed by the unbaptized Philemon. Philemon then prays, a cloud descends, and he declares himself baptized.

The judge begs him to reconsider, reminding him what a great loss the art world would suffer if Philemon were martyred. Philemon is unmoved. He challenges his torturers and the observing crowd, united in their anxiety over the prospective fate of their favorite entertainer: "Before I became a flute player, my colleagues would strike me on the face, and you would laugh. Now that I am struck for my faith in

${ }^{56}$ The text can be found in Acta Sanctorum 7 (March, vol. 1) 751-53 in Latin, and 887-91 in Greek. For historic Christians deceiving the authorities by sending their pagan friends or slaves to sacrifice in their place, see Maijastina Kahlos, Forbearance and Compulsion: The Rhetoric of Religious Tolerance and Intolerance in Late Antiquity (London: Duckworth, 2009) 46.

${ }^{57}$ Clothing even confirms visually and finalizes the conversion of an actor participating in mock baptism; see Nikki K. Rollason, Gifts of Clothing in Late Antique Literature (London: Routledge, 2016) 139. For such mock baptisms, see below. 
Christ, you are sad, but the angels are cheerful and rejoice." 58 Echoing a mimic fool (stupidus) receiving blows to elicit laughs, the would-be Christian martyr is instead struck to inherit eternal life. ${ }^{59}$ Philemon remains an object of shaming and violence, yet neither harms him. His new faith requires renunciation of his former self. In an extravagant gesture Philemon requests that a new cloud, this time of fire, burn his flutes. The instruments of his profession are indeed burned in the hands of Apollonius the deacon who, disguised as Philemon, had momentarily joined the pagan crowd. As the flutes disappear in smoke, together with Philemon's dishonorable stage career, Apollonius has a change of heart. He proclaims his faith, is arrested, and the two meet a heroic death.

Philemon's story shows how a charade, originally conceived as a stratagem in exchange for monetary gain, ultimately turns deadly. The mime actor/musician assumes not only the deacon's mantle but also the very spirit that should have infused a man of the cloth. Philemon acts precisely as Apollonius should have acted, by courageously confessing the creed publicly, regardless of dire consequences. The theatricality of the proceedings becomes obvious, as we reflect that trial and theater are both performed in public and are designed to arouse passionate emotions. Mockery is the food of the mime, but Philemon, having turned his back on both his professions, mocks his audience instead of being mocked himself.

In the martyrdom of Philemon, a Christian foundational tale reclaims and appropriates the aggressive ridicule of the mimic stage that, among other targets, poked fun at the peculiarities of creeds and their believers. A group of late ancient martyrologies preserves another scenario, featuring a troupe of mime actors pretending to be Christian priests and catechumens enacting Christian baptism. ${ }^{60}$ The catechumen is played by the stock mimic character of the simpleton stupidus, precisely the type that the pre-Christian Philemon used to embody. The martyrdom narrative would highlight the audience's hilarity at the "comedy" of immersion in

${ }^{58}$ Translated from the Greek Acts of Philemon, Apollonius, and Arrian 6; Acta Sanctorum 7, p. 888.

${ }^{59}$ For the buffoon (stupidus) as the true star of mimic comedy, see Ruth Webb, Demons and Dancers: Performance in Late Antiquity (Cambridge: Harvard University Press, 2008) 96, and for the violence inflicted on him, 117. For Paul as a mimic fool in 2 Cor 11 (the flight from Damascus), see Larry L. Welborn, "The Runaway Paul," HTR 92 (1999) 115-63.

${ }^{60}$ All of the relevant texts are preserved, like the martyrdom of Philemon, in Acta Sanctorum and date to the 4th-5th cents. CE. For a story involving the emperor Julian celebrating his birthday with precisely such a mime show, see Acta Sanctorum Sept. 5.37, with Hermann Reich, Der Mimus. Ein literar-entwickelungsgeschichtlicher Versuch (Berlin: Weidmann, 1903) 200. For an overview of the main stories and their sources, see Richard Lim, "Converting the UnChristianizable: The Baptism of Stage Performances in Late Antiquity," in Conversion in Late Antiquity and the Early Middle Ages: Seeing and Believing (ed. Kenneth Mills and Anthony Grafton; Studies in Comparative History 4; Rochester, NY: University of Rochester Press, 2003) 84-126. For a fuller list, see Werner Weismann, "Gelasinos von Heliopolis, ein Schauspielermärtyrer," AnBoll 93 (1975) 39-66, at $41 \mathrm{n}$. 1. For an evaluation of the theatrical pieces of information preserved in these stories, see Costas Panayotakis, "Baptism and Crucifixion on the Mimic Stage," Mnemosyne 50 (1997) 302-19. 
which fools engage, only to demonstrate the ultimate power of baptism. "I truly am a Christian," the actor would proclaim as he is miraculously converted to Christianity through a simple dip in water. ${ }^{61} \mathrm{He}$ is then swiftly martyred before anyone has the time to ask how conversion can circumvent conscious decision making. ${ }^{62}$

\section{Mocking the Divine}

Mockery of matters pertaining to religion and rite was hardly novel in late antiquity. Old comedy had already poked fun at the mythological burlesques of gods and goddesses in plots constructed around a comic clash between their divine status and actual comportment. ${ }^{63}$ Although no mythological mimes have survived, echoes of mimic plots in literature do feature the gods. Ovid (first century BCE-first century $\mathrm{CE}$, Rome) unfolds the origins of the festival of Anna Perenna, an older female goddess who would be expected to act as a go-between for illicit lovers. ${ }^{64}$ When Mars asks her to convey his love to the youthful Minerva, Anna pretends that she has done so, and Mars happily sets out to receive his new lover. The would-be "bride" is escorted, duly veiled, to the bedchamber. When Mars moves to kiss her, he discovers not Minerva but the old and undesirable Anna, to the merriment of all the gods, including Venus, Mars's own wife. Adultery thwarted, the powerful god of war is made a fool. There are hints that late antique audiences delighted, as much as their predecessors, in watching their divinities humiliated on the mimic stage. Tertullian (second century CE, North Africa) censures actors who dress up as Saturn, Isis, or Liber and who submit to the indignity of being slapped. ${ }^{65} \mathrm{He}$ further provides a list of titles for mimes that feature gods, including one that casts the god Anubis as an adulterer and another that features a "flogged Diana."

Above all, however, the mime's staple was the life and adventures of ordinary people. A list of mime characters provided by Choricius of Gaza (sixth century CE) includes a master, servants, innkeepers, sausage sellers, cooks, a host, banqueters, people making contracts, a babbling child, a youth in love, an angry man, another

${ }^{61}$ See the martyrdom of Gelasinos, who emerges from the baptismal pool to proclaim his Christianity, adding "I saw the astounding power of God in my baptism in the tub and I die a Christian" (Malalas, Chronographia 12.50).

${ }^{62}$ Cf. Susanna Elm, "Marking the Self in Late Antiquity: Inscriptions, Baptism, and the Conversion of Mimes," in Stigmata-Körperinschriften (ed. Bettine Menken and Barbara Vinken; Paderborn: Fink, 2003) 47-68, who casts doubt on the importance of "consciousness" and intentionality as markers of genuine conversion in late antiquity.

${ }^{63}$ For the mime's debt to this comic tradition, see Panayotakis, "Baptism and Crucifixion," $304-5$.

${ }^{64}$ See Ovid, Fast. 3.675-96. For the story as a mimic plot, see Timothy Peter Wiseman, Roman Drama and Roman History (Exeter: University of Exeter Press, 1998) 72-73.

${ }^{65}$ De spectaculis 23.

${ }^{66}$ Apologeticum 15. "Anubis the adulterer" could owe something to the famed Egyptian Tale of the Two Brothers, where a character named Anubis rejects the advances of his brother's wife. Other titles mentioned by Tertullian in the same passage include a "masculine Moon" and the "three starving Herculeses"; what these plays would contain remains a mystery, but the mockery and humiliation of the gods is a given. 
man calming him down. ${ }^{67}$ No female roles are listed among the stock characters. The omission is noteworthy. Choricius's treatise aspired to defend mimes (its full title: On Behalf of "Those Who Represent Life (Biologoi)" in the House of Dionysus), and his list conceals their most scandalous aspect, namely, the inclusion of females in acting troupes. Indeed, it was only on the mimic stage that women performed alongside male actors. ${ }^{68}$ Their presence, although vouchsafing the authenticity of the enacted proceedings, particularly in adultery mimes, often proved problematic and, for Christians, a mortal danger. The following section explores the structure and staging of female performances in mimes, highlighting intriguing parallels between adultery mimes and LamR Pr 24.

\section{Mime and Adultery}

Not only did women perform in mimes, exposed to the unwary and potentially desirous male gaze, but, given the popularity of mimes featuring adulteresses, female actresses had to perform on a bed. Adultery mimes ordinarily revolved around a married woman who allows a lover to invade the marital space, where they are invariably surprised by the cuckolded husband who bursts through the doors and (almost) catches the two lovers in flagrante delicto ${ }^{69}$ Frantic attempts to hide a lover provoked endless mirth. Audiences laughed at the search of a suitable hiding place (laundry baskets, mangers, jars), as well as at the husband's hunt of the concealed lover and the excuses concocted by the wife. ${ }^{70}$ Action likely extended from the visual to the audible as the mimic lover betrayed himself through natural vocal impulses, such as sneezing when hiding in a wicker basket or when he is accidently trodden upon while hiding under a wooden trough. ${ }^{71}$ Rachel, hidden yet vocal underneath the nuptial bed, is both an echo and a revision of the mimic adulterer: like him, she is banned into simulation, but unlike him, she is in control of the situation, her voice serving not to reveal but to conceal her even further.

A papyrus fragment from Egypt (Oxyrhynchus, second century, P.Oxy 413) provides the only two mime scripts to have (partly) survived. One presents the rescue of a Greek girl, named Charition and held captive in India, by her brother and his sidekick, the "fool." ${ }^{72}$ This script includes stage directions to actors, leaving

${ }^{67}$ Choricius, Or. 32.110, cited in Webb, Demons and Dancers, 99. For evidence that 6thcent. Christian audiences may themselves have enjoyed the mime's ridiculing of clergy, monks, and ascetics, see ibid., 127.

${ }^{68}$ See Ernst Wüst, "Mimos," $R E$ 15.2, col. 1752. Mime troupes must have included female performers already from the end of the 5th cent. BCE; see Andreas Fountoulakis, "The Artists of Aphrodite," L'Antiquité Classique 69 (2000) 133-47.

${ }^{69}$ On the motif of "bursting through the doors," see Webb, Demons and Dancers, 117-18.

${ }^{70}$ The motif migrated from the stage to literature (love poetry, satire, and novel): see Propertius 2.23.9-10; Ovid, Ars 3.608-9; Horace, Sat. 2.7.59-82; Juvenal, Sat. 6.42; Apuleius, Metam. 9.

${ }^{71}$ Both examples are taken from Apuleius, Metam. 9.

${ }^{72}$ For an overview of the two plots, see Webb, Demons and Dancers, 108-11; Walter Puchner, Greek Theatre between Antiquity and Independence: A History of Reinvention from the Third Century BC to 1830 (Cambridge: Cambridge University Press, 2017) 27-30. For convincing 
considerable room for improvisation. The other papyrus script, which its editor titled "The Adulteress" (Moicheutria), depicts the female protagonist as a lustful woman desiring her slave and bent on killing her husband. ${ }^{73}$ Here, the leading mime actress (archimima) plays an archvillain, who, worryingly for a male audience, could be the woman next door. Unlike the equally passionate and dangerous heroines of classical tragedy who are distanced from the viewer through their secure placing in the realm of myth, the women of the adultery mimes were firmly planted in the same world as their audience. ${ }^{74}$ In "The Adulteress," the protagonist is spurned by her own slave, Aesop. Having unabashedly declared her desire, the mistress condemns both the slave and the woman he really loves, Apollonia, to death. ${ }^{75}$ She is, however, thwarted by the slaves entrusted to carry out her commands. Aesop's corpse is produced in a charade aiming to convince her that her favorite slave is dead. Indeed, his mistress mourns both him and her unrequited passion: "Poor fool, so you preferred to be cast out like this, rather than be my lover? Deaf he lies, how shall I mourn him?” (11. 36-37 Cunningham).

The adulteress now embarks on a plan to make away with her husband and the household slaves, sell the property, and retire. In quick succession, the husband is summoned for a feast of apparent reconciliation that is laced with poisoned mead and which is further applied to get rid of the entire corps of slaves. As a trio of corpses (Aesop, Apollonia, the husband) is displayed on stage (none really dead), the widowed mistress feigns a tragic lament over her husband, to which a slave offers a mocking echo. In the margin of the papyrus, this contest of dirges is signposted by the word "competition" (agôn). ${ }^{76}$ As was suggested above, this strategy of heaping laments, some "genuine" and tragic, some mocking and comic, is employed to great effect in LamR Pr 24. Here, the villainous wife bewails the husband she herself (thinks she) killed: "Father and master, to whom are you leaving me? I have lost my freedom of speech, my glory, my light of liberty" (11. 75-79 Cunningham). An effeminate slave named Málacus ("Softie" 77 ) offers a comic version: "Woe to

arguments on the use of the scripts, see Stavros Tsitsiridis, "Greek Mime in the Roman Empire (POxy 413): Charition and Moicheutria," Logeion 1 (2011) 184-232.

${ }^{73}$ Versions of this mimic adulteress, who uses her slaves for her sexual gratification, survive in Herodas's Mimiamb 5 and the Life of Aesop; on the latter text, see Konstantakos, "Aesop Adulterer and Trickster," who also notes that the vast majority of adultery mimes feature a female as the adulterous protagonist, while only a few would attach craftiness and enterprise to the male lover.

${ }^{74}$ See Webb, Demons and Dancers, 111-12, who contrasts the "adulteress" with Clytemnestra and emphasizes the shock her crude language would provoke.

${ }^{75}$ The text is printed as Fr. 7 in Cunningham, Herodae Mimiambi. Translations are adapted from Denys Lionel Page, Greek Literary Papyri (2 vols.; LCL; Cambridge: Harvard University Press, 1942) 1:350-61.

${ }^{76}$ As pointed out by Tsitsiridis, "Greek Mime," 193. We also follow his attribution of the first dirge to the murderous wife and not to one of the slaves.

${ }^{77}$ His name is the same as the adjective "soft," the only difference being the raised accent, which would be indicative of a pet. On this character, see, further, Mario Andreassi, "La figura del 'Malakos' nel mimo della 'Moicheutria,'” Hermes 128 (2000) 320-26. 
you, miserable, hapless, troublesome, unlovable man! Woe to you!" "Woe to me!" shouts the old man as he leaps from his bier, followed by the "resurrected" Aesop and Apollonia. The papyrus breaks off here, surely near the end of the play itself, which must have concluded with a song celebrating the punishment of the adulteress.

A mime play like this one was, by its construction, subversive and menacing. On stage was a woman playing the part of a murderous "adulteress," face uncovered and brazenly dwelling on the bodily desires of her persona. Not surprisingly, mime actresses were invariably identified with prostitutes, females wholly subsumed by their sexual promiscuousness. In fifth-century Antioch - a city notorious for its nightlife and its refulgent street lights - the future Saint Pelagia is presented as, interchangeably, a mime actress (mimas) and a prostitute (pornê) who earns a great deal of money from her innumerous lovers. ${ }^{78}$ Theodora, wife of Justinian (sixth century), is portrayed in a vituperative account by Procopius as a child prostitute maturing into a mime actress with a penchant for titillating stage acts. ${ }^{79}$

Criticism leveled at both the mime and its spectators, always present, intensifies with the rise of Christianity. In the second century CE, Plutarch, a Greek moralist, castigates the paignia, shows of buffoonery and scandal, as unfit even for slaves' eyes. ${ }^{80}$ A century later the Christian Lactantius weighed in: "What should I say about the mimes which offer a training in corruption, teaching acts of adultery while representing it (on stage) (docent adulteria dum fingunt)?" ${ }^{81}$ In late fourth-century Antioch, Chrysostom, the redoubtable city bishop, reviled the mimic actress and her "languid gaze, her curly hair, her smooth cheeks and kohl-rimmed eyes." Such strictures suggest that, for the Christian bishop, male audiences could not possibly have remained unaffected while sitting in the theater as though "under siege" by burning desires and receiving heaps of "injuries" showered from the stage. ${ }^{82}$

\footnotetext{
${ }^{78}$ Pelagia is first introduced (paragraph 4 ) with reference to both mime and pantomime; she is "the first among the mime actresses of Antioch and also the first among the chorus dancers of the orchêstês [pantomime dancer]." After her conversion, she will don male clothing and live the rest of her life as the hermit Pelagios. The Greek text (in multiple recensions) can be found in Pélagie, la pénitente. Métamorphoses d'une légende (ed. Pierre Petitmengin et al.; 2 vols.; Paris: Études Augustiniennes, 1981-84) 1:77-131. An Italian translation was published recently; see Laura Franco, Cinque Sante Bizantine. Storie di cortigiane, travestite, eremite, imperatrici (Milan: SE, 2017) 21-36. On Antioch's active and notorious nightlife, see Ammianus Marcellinus 14.1.9 and Libanius Or. 11.267.

${ }^{79}$ See his Secret History 9.20-23, with David Potter, Theodora: Actress, Empress, Saint (Oxford: Oxford University Press, 2015) 39-59.

${ }^{80}$ See his Symposiaca 7; 8.712a, with Tsitsiridis, "Greek Mime," 184-85, for the distinction between these paignia and the lengthier, more elaborate hypotheses.

${ }^{81}$ Lactantius, Inst. 6.20.30, with Webb, Demons and Dancers, 171; her chapters 7 and 8 are useful overall for critiques of the theater, stretching from Plato's rejection of theatrical mimesis (155) to Augustine's sorrowful recollections of himself as a young man enjoying an adultery mime (190-91 on Confessions 3.2).

${ }^{82}$ Chrysostom, Hom. Jo. 18.4 and 60.5, with Blake Leyerle, Theatrical Shows and Ascetic Lives: John Chrysostom's Attack on Spiritual Marriage (Berkeley: University of California Press, 2001) 68-69.
} 
An anonymous preacher, whose sermon "Against the Theater" (Contra theatra) was attributed to John Chrysostom, scolded his male parishioners for activating a roving eye in the theater rather than fixing a pious glance on the altar:

Have you no fear, fellow Christians, bending the same eyes at a bed in the orchestra where abominable dramas of adultery are performed, while [avoiding] this sacred table where the mysteries are celebrated? - Do not tell me that this is mere play-acting! Such play-acting has made many men adulterers and has destroyed many families. ${ }^{83}$

Simulated sex on a stage bed easily stimulated desires for illicit affairs and voyeuristic fantasies. ${ }^{84}$ It rendered considerably more difficult the envisioning of Christ's blood in a cup of wine carefully poured in a church. Whether adultery mimes played a role in breaking up families and in transforming family men into adulterers is unclear, and perhaps unlikely. What does seem clear is that in the minds of Christian preachers, mime represented the opposite of piety. It unfolded scandals, dangers, and violence. In fact, the outspokenness of mimes, largely unscripted and hence easily appropriated for different contexts, often posed a threat not to audiences but to authors and performers who leveled mimic mockery at the powerful in society. ${ }^{85}$ The theater was the natural space of parresia (license to speak freely), but this too had its limitations. In the following section, we examine rabbinic narratives that suggest that even in synagogal spaces, theatrical parrēsia was similarly double-edged, and mime's techniques were employed to soothe spirits, mediate conflicts, and give voice to those society excluded. Rachel's intervention in the midrash relies precisely on such a notion of theatrical parrēsia. In her mimic performance, she finds a voice powerful enough to challenge the ultimate authority.

\section{E. Mime and Midrash}

Rabbinic midrash provides intriguing and conflicting testimonies regarding mime in Palestine. In Caesarea, capital city of the Palestinian provinces, Jewish customs, such as the sabbatical year and the Sabbath, were mocked on stage. ${ }^{86}$ What made

${ }^{83}$ For the Greek text, see PG 56.543. The translation is taken from R. W. Reynolds, "The Adultery Mime," CQ 40 (1946) 77-84, at 80, who, however, takes the sermon to be by John Chrysostom. The mimic bed could find other uses apart from the staging of adultery: in De Davide et Saule 3 (PG 54.696-97), Chrysostom says that the mime play that led to the martyrdom of St. Gelasius at some point featured the actor lying ill on a bed.

${ }^{84}$ The depraved emperor Heliogabalus (218-22 CE) reportedly instructed mimes to perform in reality what would otherwise only be simulated; see Lamprid. Heliog. 25.4, with Reynolds, "The Adultery Mime," 79; and Webb, Demons and Dancers, 107.

${ }^{85}$ According to his biographer, Suetonius, the Flavian emperor Domitian executed Helvidius Priscus the Younger, a statesman and a writer, for having ridiculed him in a mime (Suetonius, Dom. 10.4). See below for the Jewish patriarch's chagrin.

${ }^{86}$ LamR Pr 17. On this text see Hagith Sivan, Palestine in Late Antiquity (Oxford: Oxford University Press, 2008) 145-46; and Zeev Weiss, Public Spectacles in Roman and Late Antique Palestine (Cambridge: Harvard University Press, 2014) 123-26. On the possibility of a Jewish athlete mocked in a Greek mime, see Allen Kerkeslager, "Maintaining Jewish Identity in the 
the mime funny was precisely the audience's familiarity with these customs. In one such skit a camel, wrapped in a shroud, was brought onto the stage, prompting a staged series of questions about this bizarre mode of mourning. The correct answer was that, because Jews were not cultivating their land every seventh year, they were forced to eat the camel's thorns. For Abbahu, Caesarea's preeminent rabbinic sage and the reporter of the Sabbatical Caesarean mime, the main point was to demonstrate the deep divide between local and Jewish denizens of Caesarea, the former wasting time sitting in theaters and circuses where they ate, got drunk and indulged in vicious gossip, the latter spending valuable time in schools and synagogues.

Rabbis, like ecclesiastics, were ready to castigate mimes. ${ }^{87}$ Like Abbahu, the Palestinian Talmud compares the toil of Torah to the industriousness displayed by spectators in theaters and circuses, the former laudable and rewarding, the latter futile and despicable:

I thank thee, my Lord, God of my ancestors, for bestowing on me the part of those who sit in study halls and synagogues rather than in theaters and circuses, seeing that I toil and so they do, and I apply myself and so they do, but whereas I head to paradise, they head to hell, as it is said: "You will not sink me into hell nor allow your devotees to be exposed to decay" (Ps 16:10). (y. Ber. $4 \cdot 2)^{88}$

To convince the divinity that the time had arrived, yet again, to save Israel from its persecutors, Rabbi Abba bar Kahana (late third century), elaborating on Jer 15:17 ("I never sat in the company of revelers nor made merry with them. Alone I sat on Your account"), reminded God of the unique connection with his people: "Said the community of Israel to the Lord: Master of the Universe, all my life I have avoided the theaters and the circuses of the nations of the world (i.e., gentiles) nor did I make merry and rejoice with them. On your account I sat apart, all by myself. . . ." 89 Linking entertainment with idolatry was meant to jolt the divine will into action, as though the self-imposed isolation of God's people warranted special consideration. At the same time, the same sage also intimated that even rabbis attended theatrical shows and circus games. ${ }^{90}$

Greek Gymnasium: A 'Jewish Load' in CPJ 3.519 (P. Schub. 37 = P. Berol. 13406),” JSJ 28 (1997) 12-33. The popularity of mime performances in Caesarea is also attested by Choricius (Defense of the Mimes 95-96).

${ }^{87}$ For comparison, including on antitheatrical polemics, see Catherine Hezser, "Self-Control in a World Controlled by Others: Palestinian Rabbinic “Asceticism' in Late Antiquity," Religion in the Roman Empire 4 (2018) 9-27.

${ }^{88}$ Transmitted anonymously, interpreting m. Ber. 4.2, attributed to Nehunia ben Hakaneh (end of 1st cent. CE).

${ }^{89}$ LamR Pr 3; Pesiq. Rab Kah. 15.2; cf. Weiss, Public Spectacles, 206.

${ }^{90}$ For the same rabbi's familiarity with the theater, see his reference to an orchêstês (pantomime dancer) at Pesiq. Rab Kah. 26.2, with Zeev Weiss, "Games and Spectacles in Ancient Gaza: Performances for the Masses Held in Buildings Now Lost," in Christian Gaza in Late Antiquity (ed. Brouria Bitton-Ashkelony and Arieh Kofsky; Jerusalem Studies in Religion and Culture 
Ambiguity, however, lingers. While bishops and rabbis competed for audiences with the theater's alluring performances, which mocked their flocks, there was no denying that Jews (and likely Christians) were employed in the theater, even as mimes. ${ }^{91}$ An encounter, scripted as a mime, between Abbahu and a man nicknamed Pentekakos ("fivefold ills") ${ }^{92}$ induces the distinguished rabbi to make a revealing admission:

Rabbi Abbahu was told that when a certain Pentekakos prays for rain, the rain will come. Abbahu sent for him and questioned him:

(Abbahu): What is your trade?

(Pentekakos): Every single day I commit five sins. I decorate [or clean] the theater, I hire the musicians and the dancers (or, prostitutes?), I bring their clothes to the bathhouse [for washing], I clap and dance in front of them, and I sound the cymbals for them.

(Abbahu): What good have you done?

(Pentekakos): One time, when I was cleaning the theater, I saw a woman standing behind a pillar and weeping. I asked her: "Why are you crying?" She responded: "My husband is imprisoned and I want to see what I can do to get him released (by working in the theater or maybe as a prostitute)."

So I sold my bed and its coverlets and gave her the proceeds, saying to her: "This is for you. Free your husband and do not sin."

(Abbahu): You are worthy of praying and having your prayers answered (y. Ta'an. 1.4).

Fundamentally separate, the anecdote pits a famous sage with a nameless theater worker, most likely a Jew. The dialogue amounts to an encounter between the rabbinic establishment and theatrical practices, ${ }^{93}$ raising the perennial question of the worthiness of an individual versus the rigidity of rules and dogma. Between the

Series 3; Leiden: Brill, 2004) 24-32, at 31; idem, Public Spectacles, 205-20.

${ }^{91}$ For the possibility of Jewish women performing in the theater, see Giuseppe Veltri, "Magic, Sex and Politics: The Media Power of Theatre Amusements in the Mirror of Rabbinic Literature," in "The Words of a Wise Man's Mouth Are Gracious" (Qoh 10, 12): Festschrift for Günter Stemberger (ed. Mauro Perani; SJ 32; Berlin: de Gruyter, 2005) 243-56.

${ }^{92}$ Weiss, Public Spectacles, 133-34 and 187-88, refers to this character as Pantokakos ("completely evil"), arguing he must have been a leading pantomime dancer. On the other hand, Martin Jacobs, "Theatres and Performances as Reflected in the Talmud Yerushalmi," in The Talmud Yerushalmi and Greco-Roman Culture (ed. Peter Schäfer and Catherine Heszer; 3 vols.; Texts and Studies in Ancient Judaism 93; Tübingen: Mohr Siebeck, 1998) 1:327-47, at 342 , argues he must have been an archimimus, because he hires female performers, commonly perceived as prostitutes (more characteristic of the mime), while conceding, however, that the dancing and playing of cymbals are more typical of the pantomime. As it can be seen from our n. 78, though, the same female performer could be both a mime actress and a dancer in the supporting chorus of the pantomime. Also, the mime play Charition, mentioned above, features the playing of cymbals, meaning this is not exclusive of the pantomime. Pentekakos (or Pantokakos) could have worked in both genres.

${ }^{93}$ Another part of the text, LamR 5.1, contains a curious allusion to a father whose two sons engage in a domestic conflict reminiscent, according to this nugget, of cockfights. For reasons that elude us, and with no support by the text itself, translators referred to these sons as gladiators in the arena. The term, zarzir, zarzar, does not bear this interpretation, since it 
theater cleaner and the freedom of an unnamed (Jewish?) prisoner stands a bed, the symbol not of marital loyalty as exemplified by the unnamed wife who is willing to do everything for her husband, but likely a stage bed, the main prop of the most popular and notorious of all mimes, the adultery mime.

Theaters and circuses, mimes and games provided venues designed to expose the ridiculous, to promote collective catharsis, and to stage mocking criticism of the authorities. In late ancient Palestine, mimes carved a place for those whose role was negated in the class-conscious society that coalesced around the figure of the Jewish patriarch (naśi'), as the following anecdote strikingly illustrates:

"Dinah daughter of Leah went out" (Gen 34:1. Cf. Gen 30:16: "and Leah went out") . . . Like mother like daughter.

Rabbi Yossi was preaching in the synagogue of Maon on "Listen to this, priests; hearken, Israel; pay attention, royal household" (Hos 5:1), which he explained as following: The Holy One intends to summon the priests to court to be judged and they will be asked:

(God): Why did you not engage in the Torah? Did you not benefit from the [Torah prescribed] twenty-four priestly gifts?

(Priests): We got none at all.

God then addressed Israel.

(God): Why did you not present the priests with their twenty-four gifts as I prescribed in the Torah?

(Israel): Because the household of the patriarch (nasi $\left.i^{\prime}\right)$ confiscated all of them.

(God/Yossi): "Hearken, royal house: the judgement is against you!" (Hos 5:1), "and this is the rule relating to the priests" (Deut 18:3). Any [violation] will turn judgment against you!

When Rabbi (the patriarch Judah Nesia II, late third century) heard about Yossi's preaching he was furious. In the evening Resh Lakish came to pay his respects to the naś $i$ ' and to ask forgiveness for Rabbi Yossi.

(Resh Lakish): We must be grateful to the nations of the world (=gentiles) for bringing mimes into the theaters and the circuses so that by [engaging audiences] through plays they prevent collusion and useless confrontations. Yossi of Maon was preaching Torah and you are upset with him?

$\left(N a i^{\prime} i^{\prime}\right)$ : Does he know any Torah?

(RL): Yes, he does.

(Nasi $\left.i^{\prime}\right)$ : Was he instructed?

(RL): Yes.

(Naśi $i^{\prime}$ : If I question him [about points raised in the Torah] will he be able to answer?

(RL): Yes.

$\left(N a s^{\prime} i^{\prime}\right)$ : Let him then come here [to be questioned].

When Yossi came the patriarch asked him: What is the significance of (Ezek 16:44) "Lo and behold. Every metaphor is one that can be understood as

alludes to fowl and not to a gladiator. The reference suggests, however, rabbinic familiarity with different, non-Jewish forms of entertainment. 
applying to you as it is said: like mother, like daughter."

Yossi responded: The daughter is a reflection of her mother, just as the generation is a reflection of its patriarch and the altar of its priests. Here [in Maon?] we [also] say: the garden is only as good as its gardener.

Resh Lakish turned to Yossi saying: I have not yet been successful in mollifying the patriarch for your initial insult and now you add another? ... The main point remains the metaphor. Leah was a harlot, and so was her daughter Dinah. (Gen. Rab. 80.1)

Resh Lakish evokes theatrical mimes and their sanctioned outspokenness in front of the authorities ${ }^{94}$ but is only momentarily successful. Like the famed biblical figures raised from the dead in LamR Pr 24, this mediation via theatrical mimesis is doomed to fail. Did his intervention, embedded in an exegetical excursion of Gen 34 (the rape of Dinah), mean to convey an impression that Yossi of Maon acted like an outspoken mime performer? Or, like Dinah and Leah, possibly also imagined as prostitutes in a mime?

Mimicry and mockery seem to underlie both Resh Lakish's quest for reconciliation between Yossi and the nasi $i$ ' in Genesis Rabbah and the patriarchal attempt to mollify God in LamR. The two narratives are permeated with a sense of the absurd. By appropriating due priestly donations, Yossi intimated that the venerable naśi' acted like Leah, a delinquent mother, both neglecting a basic duty. Leah should have kept her daughter indoors; the naśi $i$ should have allowed the priests to benefit from donations. Like everyone else in this drama, God, too, is a character. ${ }^{95}$ Yossi of Maon cast God as a petulant patriarch, expecting to be cherished. The naśi', acting like a god, deems himself grossly insulted by a "nobody" from a small desert settlement, but instead of asserting that a synagogue is not a theater and a preacher is not a mime actor, he questions Yossi's authority to provide biblical interpretation in public.

${ }^{94}$ For a similar point regarding mimes and political satire, see Choricius's Defense of the Mimes (Or. 32.119-20), also adduced as a parallel for Resh Lakish by Weiss, Public Spectacles, 128. An earlier parallel can be found in Libanius's Defense of the Pantomime (Or. 64.91), where the 4th-cent. Antiochene orator claims that the songs accompanying the pantomime dancer's performance soothe the spirit, which in times of peace could boil up and become a stimulus for revolt.

${ }^{95}$ As shrewdly observed by Stern, "Imitatio Hominis," 157. 


\section{Conclusion}

In this study we took Rachel's "bed trick" as a mimic liturgy and asked how the entire theo-drama that LamR Pr 24 unfolds reconfigures relations between individuals, morality, and God. ${ }^{96}$ We explored how a midrashic drama based on the Hebrew Bible and patently cast as a theatrical mime, transforms a problematic biblical figure into the epitome of the humane, precisely the trait that God conspicuously lacks. Above all, we reclaimed Rachel as a milestone in a comparative context of staged adultery and of martyrdom in late antiquity. LamR Pr 24 provides invaluable clues to decipher the gap of discourse between the perennially popular adultery mime and martyr tales, on the one hand, and the rabbinic appropriation of (and response to) these tales, on the other.

Mime shamed everything and everybody: a murderous wife, a gullible husband, Jewish rites and regulations, Christian rituals, and gods who fall into the traps set for human emotions. Underlying this universal shaming was a conviction that sinning is never far from human horizons. We may well ask, then, whether mime, besides lending shaming a significant comic tinge, also indicates that the very exposure of shaming has the potential of atonement. And, if so, is shaming invariably inflicted by an external agency or is it self-induced? A singularly original answer, incorporated in rabbinic reflections on destruction and dispersion, positioned a female agent shaming God into remorse and repentance by making him realize the full cost of revenge on the self.

An adultery mime invariably features the untimely return of the cuckolded husband. In the narrative of Genesis, Rachel is altogether absent. There is no intrusion or sudden return. Only Jacob and Leah are in bed. LamR, however, returns Rachel to the stage, not to reveal or revile but to conceal herself under the nuptial bed while sex takes place "in the open," right above her. This is an ingenious literary move: a perfect foil to the proverbial theatrical search for a hiding place where the lover stays concealed while the wife tries to convince her husband that nothing had transpired in his absence.

LamR Pr 24 achieves its narrative homogeneity through a strategy of a double "excursion," beginning with a divine "tour" of ruined Jerusalem and ending with a virginal "foray" into domestic intimacy. Along the road, prominent biblical protagonists are enlisted, each delving into their own past, as though such memories have the power of moving the seemingly forgetful God. In each case the character's

${ }^{96}$ On the "bedtrick" (stories where at least one lover is duped as to the identity of the person who shares his/her bed), see Wendy Doniger, The Bedtrick: Tales of Sex and Masquerade (Worlds of Desire: The Chicago Series on Sexuality, Gender, and Culture; Chicago: University of Chicago Press, 2000). The book highlights the power of sexual illusion (477), where sex is a game whose rules are designed and destined to be broken (480). Ultimately, she argues, "the bedtrick is an exercise in epistemology" (491), meaning self-knowledge and identity. And, while tales of a bedtrick do not solve the basic problem of identity (7), they do provide a way to approach it through narrative, precisely by focusing on sex, to the exclusion of other aspects of identity. 
vaunted acts of "martyrdom" faithfully reproduce the biblical text. Only Rachel forges an autobiography with startling originality that reproduces the equally stunning novelty of God's departure from God's own habitual realm. The result is a text unparalleled in its subtle experimentation with forms of mime scripts, visual culture, and Christian Apocrypha and martyrologies. 